\title{
The Retroactivity of Substantive Rules to Cases ON COLLATERAL REVIEW AND THE AEDPA, WITH A SPECIAL FOCUS ON MILLER V. ALABAMA
}

\author{
JASON M. ZARROW* \\ WILLIAM H. MILLIKEN**
}

\section{INTRODUCTION}

In the 1960s, beginning with its decision in Mapp v. Ohio, the Warren Court effected a dramatic expansion of the constitutional rights of criminal defendants. ${ }^{1}$ This expansion prompted the Court to confront, for the first time, the "retroactivity problem" - that is, the extent to which United States Supreme Court decisions announcing "new" rules of constitutional law would apply to defendants who had been convicted of an offense prior to the rule's articulation. ${ }^{2}$ Struggling to reconcile the states' interests in finality and orderly administration of their criminal justice systems with individual defendants' constitutional rights, the Court initially meandered in its effort to create a workable solution to this

* Harvard Law School, J.D., 2013. Jason Zarrow is currently an associate at O’Melveny and Myers LLP.

** Harvard Law School, J.D., 2013. William H. Milliken is a law clerk to the Honorable Sandra L. Lynch, Chief Judge of the United States Court of Appeals for the First Circuit.

1. See, e.g., Mapp v. Ohio, 367 U.S. 643, 655 (1961) (holding that the exclusionary rule applies to state criminal proceedings); see also Miranda v. Arizona, 384 U.S. 436, 444 (1966) (holding that statements stemming from custodial interrogation of a defendant are not admissible in state criminal prosecutions unless the state employed "procedural safeguards effective to secure the privilege against self-incrimination"); Gideon v. Wainwright, 372 U.S. 335 (1963) (holding that the Sixth and Fourteenth Amendments confer a right to counsel on indigent defendants in state felony prosecutions).

2. See, e.g., Linkletter v. Walker, 381 U.S. 618, 619-20(1965) (considering whether Mapp's holding that the exclusionary rule applies to the states "operates retrospectively upon cases finally decided in the period prior to Mapp").

As will be explained in greater detail, infra, a case announces a "new rule" of constitutional law if "the result in th[e] case "was not dictated by precedent existing at the time the defendant's conviction became final." Danforth v. Minnesota, 552 U.S. 264, 270 (2008) (quoting Teague v. Lane, 489 U.S. 288, 301 (1989) (plurality opinion)) (emphasis in original). Importantly, a decision announcing a "new rule" of constitutional law does not create the rule in question; rather, it merely articulates, for the first time, a rule that the Constitution required all along. See id. at 285-86, 29091 ("It is important to keep in mind that our jurisprudence concerning the 'retroactivity' of 'new rules' of constitutional law is primarily concerned, not with the question whether a constitutional violation occurred, but with the availability or nonavailability of remedies.”). As Justice Scalia explained in American Trucking Associations, Inc. v. Smith, because "the Constitution does not change from year to year," if the Supreme Court announces that a particular governmental act violates the Constitution, that act necessarily violated the Constitution both before and after the Supreme Court's decision holding the act unconstitutional. Am. Trucking Ass'ns Inc. v. Smith, 496 U.S. 167, 201 (1990) (Scalia, J., concurring). 
problem. ${ }^{3}$ It finally arrived at a resting place in Teague v. Lane, ${ }^{4}$ in which a plurality of the Court adopted the view Justice Harlan espoused in Mackey $v$. United States $^{5}$ that new constitutional rules of criminal law always apply to cases on direct review but do not apply to cases that become final on direct review before the new rule is announced. ${ }^{6}$

Like any good rule, however, this one admits an exception (or two). The general bar on retroactive application of constitutional rules of criminal law to cases on collateral review does not apply to substantive rules-those that "narrow the scope of a criminal statute by interpreting its terms" or "place particular conduct or persons covered by the statute beyond the State's power to punish" - or to watershed rules of criminal procedure that implicate the fundamental fairness of the trial and correct a serious likelihood of an inaccurate conviction. ${ }^{8}$ This Article focuses on Teague's substantive-rule exception. ${ }^{9}$ As will be explained below, this exception has an impressive historical pedigree. It is derived directly from the core function of habeas corpus review for prisoners held pursuant to judicial process - a means by which a prisoner can secure release by challenging the court's jurisdiction to impose the punishment.

Courts undertaking the inquiry mandated by Teague have run into numerous difficulties, not least of which is the difficulty of distinguishing between

3. See generally Danforth, 552 U.S. at 293-303 (Roberts, C.J., dissenting) (describing the course of the Court's retroactivity jurisprudence).

4. Teague, 489 U.S. at 288 (plurality opinion).

5. Mackey v. United States, 401 U.S. 667 (1971) (Harlan, J., concurring in part and dissenting in part).

6. Id. at 682-94; see also Desist v. United States, 394 U.S. 244, 256-69 (1969) (Harlan, J., dissenting) (criticizing the Court's retroactivity decisions and suggesting an approach to retroactivity premised on the distinction between direct and collateral review).

7. Schriro v. Summerlin, 542 U.S. 348, 351-52 (2004).

8. Teague, 489 U.S. at 311-14. The Court has since clarified that Teague is properly applicable only to procedural rules of constitutional law, and hence that substantive rules are not technically "exceptions" to the Teague bar, but rather simply "not subject to the bar." Schriro, 542 U.S. at 352 n.4. For ease of exposition, we will occasionally refer to the "substantive-law "exception"" to Teague's rule of nonretroactivity on collateral review. This choice of words, however, should not obscure the point that the Teague bar operates only on procedural rules.

9. In this Article, we focus not on the Teague "exceptions" as a unit but only on the principle that substantive rules are retroactively applicable on collateral review. This is because the Teague exception for "watershed" rules of criminal procedure is exceedingly narrow, almost to the point of being a "null set." Richard H. FALLON, JR. ET AL., HART \& WECSHLER's THE FEDERAL COURTS AND THE FEDERAL SYSTEM 1246 (6th ed. 2009); see also Sepulveda v. United States, 330 F.3d 55, 61 (1st Cir. 2003) (noting that "examples of watershed rules are hen's-teeth rare"); Kermit Roosevelt III, A Little Theory is a Dangerous Thing: The Myth of Adjudicative Retroactivity, 31 ConN. L. REV. 1075, 1123 (1999). They are thus of little practical import. See infra Part III. Additionally, we argue below that Teague's substantive-rule exception may stand on a different constitutional plane than its exception for watershed procedural rules. See infra Part V. 
substantive and procedural rules. ${ }^{10}$ The distinction is extremely important, since a determination that a given rule is procedural essentially means that the rule will not be retroactively applicable. ${ }^{11}$ A determination that a rule falls within Teague's substantive-rule exception, however, means that it will operate retroactively. ${ }^{12}$

Despite the difficulties Teague presented, for a time, it provided a relatively concrete method for assessing the applicability of new rules - even if that method was not always easy to apply in practice. Such was the state of the law until Congress passed the Antiterrorism and Effective Death Penalty Act ("AEDPA"), which wrought substantial changes to the law governing prisoners' collateral attacks on their convictions in federal court. ${ }^{13}$ Most importantly for purposes of this Article, the AEDPA amended 28 U.S.C. $§ 2254(d)$ to provide as follows:

An application for a writ of habeas corpus on behalf of a person in custody pursuant to the judgment of a State court shall not be granted with respect to any claim that was adjudicated on the merits in State court proceedings unless the adjudication of the claim-

(1) resulted in a decision that was contrary to, or involved an unreasonable application of, clearly established Federal law, as determined by the Supreme Court of the United States . . . . ${ }^{14}$

The interaction between $\S 2254(\mathrm{~d})(1)$ and the Court's Teague jurisprudence was unclear in the initial years following the AEDPA's enactment, ${ }^{15}$ and it remains so today. Specifically, query whether $\S 2254(\mathrm{~d})(1)$ incorporates the principle that substantive rules are retroactively applicable to cases on collateral review. That is, would the statute bar a federal habeas petitioner from relying on a Supreme Court decision announcing a new substantive rule that was handed down after the last state-court decision on the merits? The Courts of Appeals have divided on this question, ${ }^{16}$ and the Supreme Court has expressly left it

10. Cf. Shady Grove Orthopedics Ass'n v. Allstate Ins. Co., 559 U.S. 393, 414-15 (2010) (plurality opinion) (noting the elusive distinction between procedure and substance).

11. See supra note 9 (explaining that the Teague exception for watershed rules of criminal procedure is so narrow as to be essentially nonexistent).

12. See, e.g., Bousley v. United States, 523 U.S. 614, 620-21 (1998).

13. 28 U.S.C. $\$ 2241$, Pub. L. No. 104-132, 110 Stat. 1214.

14. 28 U.S.C. $\S 2254(\mathrm{~d})(2012)$.

15. Compare Williams v. Taylor, 529 U.S. 362, 380 n.12 (2000) (opinion of Stevens., J.) (AEDPA "codif[ied] into law" the Teague doctrine), with id. at 412 (opinion of O'Connor, J.) ("[T]he 'clearly established Federal law' phrase bears only a slight connection to our Teague jurisprudence."); see generally A. Christopher Bryant, Retroactive Application of "New Rules" and the Antiterrorism and Effective Death Penalty Act, 70 GEO. WASH. L. REV. 1, 17-23 (2002) (describing the Williams opinions' "conflicting exegeses" of $\S 2254(d)(1)$ ).

16. Compare Danforth v. Crist, 624 F.3d 915, 918-19 (8th Cir. 2010) (assuming without analysis that $\S 2254(\mathrm{~d})(1)$ incorporates the Teague exceptions but denying relief on the basis that the rule invoked by the habeas petitioner was not a watershed rule of criminal procedure), and Blintz v. Bertrand, 403 F.3d 859, 864-67 (7th Cir. 2005) (same), and Bockting v. Bayer, 399 F.3d 
open. ${ }^{17}$

The ultimate resolution of this question is of tremendous importance from both a practical and a constitutional perspective. On the practical side, a habeas petitioner subject to $\S 2254(d)(1)$ who seeks the benefit of a new substantive rule-for example, an individual who was convicted under a state statute that was ruled unconstitutional after the individual's conviction became final-will not be able to obtain federal habeas relief unless $\S 2254(\mathrm{~d})(1)$ is read to incorporate the principle of retroactivity of substantive rules. On the constitutional side, we argue below that the substantive-rule exception to nonretroactivity has roots in the Due Process Clause and the Suspension Clause of the United States Constitution. Reading § 2254(d)(1) to eliminate this exception would thus have serious constitutional implications. ${ }^{18}$

Notwithstanding the importance of the issue, it has received very little attention from courts or commentators. ${ }^{19}$ Most of the court opinions to address the question have dealt with it in rather cursory fashion, oftentimes in dicta. ${ }^{20} \mathrm{In}$ fact, while the Teague decision has spawned a body of literature and case law that, to borrow a phrase from another context, is nearly "choking on redundancy," 21 the substantive-rule exception to Teague has rarely been discussed. And the Court itself has only rarely applied the principle that substantive rules are retroactively applicable on collateral review. ${ }^{22}$

A likely reason for the lack of focus on the substantive component of Teague is the fact that the Court's retroactivity jurisprudence was a response to the Warren Court's "rights revolution," which, by and large, promulgated new rules of criminal procedure, not new substantive rules of criminal law. But, in recent years, the Supreme Court has reinvigorated its Eighth Amendment jurisprudence, continuously reevaluating "the evolving standards of decency that mark the

1010, 1021 (9th Cir. 2005), rev'd on other grounds sub nom Whorton v. Bockting, 549 U.S. 406 (2007) (holding that the AEDPA incorporates the Teague exceptions), and Lewis v. Johnson, 359 F.3d 646, 653-54 (3d Cir. 2004) (apparently assuming that § 2254(d)(1) incorporates the Teague exceptions but finding neither section applicable to the habeas petitioner's claim), and Cockerham v. Cain, 283 F.3d 657, 660-61 (5th Cir. 2002) (noting the Fifth Circuit's position that Section 2254(d)(1) does incorporate the Teague exceptions), with Gosier v. Welborn, 175 F.3d 504, 510 (7th Cir.1999) (noting in dicta that "[s]ection 2254(d)(1) differs from Teague because the . . statute closes the escape hatches in Teague"), and Ramdass v. Angelone, 187 F.3d 396, 406 n.4 (4th Cir. 1999), aff'd in part, 530 U.S. 156 (2000) (same).

17. See Greene v. Fisher, 132 S. Ct. 38, 44 n.*(2011).

18. We intend to explore these questions in further depth in a subsequent article.

19. See infra note 128 and accompanying text.

20. See infra notes 126-27 and accompanying text.

21. Gerald Gunther, Congressional Power to Curtail Federal Court Jurisdiction: An Opinionated Guide to the Ongoing Debate, 36 STAN. L. REV. 895, 922 n.9 (1984).

22. For one of the few decisions applying this principle, see Bousley v. United States. 523 U.S. 614, 620-21 (1998). Bousley, however, unlike the other cases articulating the substantive-rule exception (see infra Part IV), involved a federal statute and thus bears only a tangential relation to the $\S 2254(d)$ inquiry regarding relief for state-court prisoners. 
progress of a maturing society" 23 in order to set forth more limitations on the punishments that states may constitutionally impose on certain classes of individuals and crimes. While a far cry from a "substantive rights revolution," the Court's increasing focus on the Eighth Amendment and its guarantees may force courts to clarify further the scope of the substantive-rule exception and decide whether substantive rules may be applied retroactively on collateral review notwithstanding $\S 2254(\mathrm{~d})(1)$.

In this Article, we use the Supreme Court's decision in Miller v. Alabama, which held that a sentencing scheme that mandates juvenile life without parole violates the Eighth Amendment, ${ }^{24}$ as a vehicle to explore two of the most difficult issues raised by Teague: the scope of the substantive-rule exception to nonretroactivity and the interaction of this exception with the AEDPA. First, we consider whether Miller, in whole or in part, is substantive under Teague and its progeny. We conclude that Miller has both a procedural component and a substantive component. The latter, simply stated, is that juveniles whose culpability falls below a certain baseline level may not constitutionally be sentenced to life imprisonment without the possibility of parole. That substantive component - which we term the "implicit rule" of Miller - should be held retroactive to cases on collateral review under Teague. In reaching this result, we explore the historical origin of the substantive-rule exception and chart its post-Teague development, ultimately concluding that it is tethered to categorical guarantees.

Second, we ask whether a petitioner sentenced in violation of Miller (or any other decision articulating a substantive rule of law) would be barred by $\S$ 2254(d)(1) from invoking that decision retroactively. ${ }^{25}$ We argue that $\S$ 2254(d)(1) should not be read to preclude relief. Our conclusion rests strongly on two bedrock canons of statutory construction - the canon of construction of the federal habeas statute that a repeal of federal habeas jurisdiction will be found only when accompanied by an exceedingly clear congressional command and the constitutional avoidance canon. Importantly, in our view, reading $\S$ 2254(d)(1) to preclude the retroactive application of substantive rules would raise serious constitutional questions about the scope of the Suspension Clause and the power of Congress to limit the Great Writ.

Our analysis proceeds as follows. In Section II, we briefly describe the evolution of the Supreme Court's retroactivity jurisprudence and analyze the Teague decision in detail. Section III discusses the Court's interpretation of $\S$ 2254(d)(1) and explains the tension between the statute and Teague, as well as

23. Miller v. Alabama, 132 S. Ct. 2455, 2463 (2012) (quoting Estelle v. Gamble, 429 U.S. 97, 102 (1976)); see also Roper v. Simmons, 543 U.S. 551, 561 (2005) (quoting Trop v. Dulles, 356 U.S. 86, 100-01 (1958) (plurality opinion)).

24. Miller, 132 S. Ct. at 2463.

25. At least one habeas challenge arising under Miller raising both issues is currently winding its way through the federal courts. See Thompson v. Roy, No. 13-CV-1524, 2014 WL 1234498 (D. Minn. March 25, 2014). The courts of appeals are also considering whether Miller is retroactive for purposes of 28 U.S.C. $\S 2255(h)(2)$. See, e.g., In re Morgan, 713 F.3d 1365 (11th Cir. 2013). 
the reason why that tension has not been resolved in the nearly twenty years since the AEDPA's enactment. Section IV analyzes Teague's substantive-rule exception, charting the doctrine's roots and recent development. That section then concludes that Miller contains an implicit rule that should be held retroactive under Teague. Section V argues that $\S 2254(d)(1)$ should be read to allow for the retroactive application of substantive rules. Section VI concludes.

\section{The Retroactivity Vel Non OF “NeW” Rules On Collateral ReVIEW}

\section{A. The Supreme Court's Early Retroactivity Jurisprudence}

This Article centers on the relationship between $\S 2254(\mathrm{~d})(1)$ and Teague's rule that substantive rules apply retroactively on collateral review. Although Teague constitutes the culmination of the Court's retroactivity jurisprudence, a comprehensive understanding of the issues discussed in this Article is not possible without some knowledge of Teague's predecessors. This Section provides a brief summary of the meandering course of the Court's retroactivity decisions. ${ }^{26}$

The Court first confronted the "retroactivity problem" in Linkletter $v$. Walker, ${ }^{27}$ which asked whether the Court's holding in Mapp v. Ohio-that the Fourth Amendment exclusionary rule is applicable to the states ${ }^{28}$-applied retroactively to state prisoners whose convictions had become final on direct review prior to Mapp. ${ }^{29}$ The Court held that it did not. ${ }^{30}$

The majority explained that "the Constitution neither prohibits nor requires retrospective effect" of decisions that include newly articulated rules of constitutional law. ${ }^{31}$ Thus, to determine whether a given rule should have retroactive effect, the Court "must ... weigh the merits and demerits in each case by looking to the prior history of the rule in question, its purpose and effect, and whether retrospective operation will further or retard its operation." 32 The Court determined that applying Mapp retroactively would do nothing to further the

26. For more in-depth analyses of the Court's early retroactivity jurisprudence, see, for example, Richard H. Fallon \& Daniel J. Meltzer, New Law, Non-Retroactivity, and Constitutional Remedies, 104 HARV. L. REV. 1731, 1738-49 (1991); Christopher N. Lasch, The Future of Teague Retroactivity, or "Redressability," After Danforth v. Minnesota: Why Lower Courts Should Give Retroactive Effect to New Constitutional Rules of Criminal Procedure in Postconviction Proceedings, 46 AM. CRIM. L. REV. 1, 8-33 (2009); Roosevelt, supra note 9, at 1081-103; Pamela J. Stephens, The New Retroactivity Doctrine: Equality, Reliance and Stare Decisis, 48 SYRACUSE L. REV. 1515, 1517-30 (1998); see also Bryant, supra note 15, at 9 n.39 (collecting authorities on the history of the Court's retroactivity jurisprudence).

27. Linkletter v. Walker, 381 U.S. 618 (1965).

28. Mapp v. Ohio, 367 U.S. 643 (1961).

29. Linkletter, 381 U.S. at 619-20.

30. Id. at 651 .

31. Id. at 629 .

32. Id. 
decision's primary purpose of deterring police misconduct and would "tax the administration of justice to its utmost." 33 The majority also noted (1) that the courts that had declined to exclude illegally seized evidence prior to Mapp had done so in reasonable reliance on Wolf $v$. Colorado ${ }^{34}$ which Mapp overruled $;{ }^{35}$ and (2) that the admission of illegally seized evidence did not impugn the reliability of the defendant's conviction. ${ }^{36}$

In Stovall v. Denno, the Court clarified and elaborated upon the retroactivity analysis set forth in Linkletter. ${ }^{37}$ The issue in Stovall was whether the holdings of United States v. Wade and Gilbert v. California, "requiring the exclusion of identification evidence which is tainted by exhibiting the accused to identifying witnesses before trial in the absence of his counsel" applied retroactively. ${ }^{38}$ The Court analyzed the question by considering three factors: "(a) the purpose to be served by the new standards, (b) the extent of the reliance by law enforcement authorities on the old standards, and (c) the effect on the administration of justice of a retroactive application of the new standards." 39 The Court reasoned that, "while ... the exclusionary rules set forth in Wade and Gilbert are justified by the need to assure the integrity and reliability of our system of justice," they were not so essential to a fair trial as to make retroactive application appropriate, given that, before Wade and Gilbert, "[t]he law enforcement officials of the Federal Government and of all 50 States ha[d] . . . proceeded on the premise that the Constitution did not require the presence of counsel at pretrial confrontations for identification." 40

The Warren Court's approach to the retroactivity problem produced "unpredictable" results and prompted widespread criticism, ${ }^{41}$ most notably from Justice Harlan in his separate opinions in Desist $v$. United States ${ }^{42}$ and Mackey v. United States. ${ }^{43}$ Because Justice Harlan's views in these cases ultimately formed the basis for the Supreme Court's Teague jurisprudence, we will analyze them in some detail.

33. Id. at 637 .

34. Wolf v. Colorado, 338 U.S. 25 (1949).

35. Linkletter, 381 U.S. at 636-38.

36. Id. at 639 .

37. Stovall v. Denno, 388 U.S. 293 (1967).

38. Id. at 294.

39. Id. at 297.

40. Id. at 299 .

41. See Fallon \& Meltzer, supra note 26, at 1734, 1742. Professors Fallon and Meltzer ultimately argue that the retroactivity problem should be analyzed within the framework of the law of remedies, and that the Stovall test "capture[s] the relevant values" in that framework. Id. at 1797. We believe that Professors Fallon and Meltzer are correct that the retroactivity problem is, at bottom, essentially a remedial issue; we explore the implications of that conclusion for our inquiry infra notes 393-94 and accompanying text.

42. Desist v. United States, 394 U.S. 244, 256 (1969) (Harlan, J., dissenting).

43. Mackey v. United States, 401 U.S. 667, 675 (1971) (Harlan, J., concurring in part and dissenting in part). 
In Desist, Justice Harlan decried the "incompatible rules and inconsistent principles" that the Court's retroactivity decisions had spawned, and concluded that "[r] etroactivity' must be rethought." ${ }^{44} \mathrm{He}$ proposed an approach to the retroactivity problem premised on a distinction between direct and collateral review. ${ }^{45}$ Justice Harlan opined that all new rules should be retroactively applicable to cases pending on direct review at the time the new rule is articulated, in view of the "truism that it is the task of this Court, like that of any other, to do justice to each litigant on the merits of his own case." ${ }^{" 46}$ But, he explained, in view of the distinct functions of a court on direct review and habeas review, a different retroactivity rule would be appropriate for the latter situation. ${ }^{47}$

Justice Harlan believed that the Linkletter approach, which focused on the purpose of the new rule, was fundamentally unsound: "[t]he relevant frame of reference," he wrote, "is not the purpose of the new rule whose benefit the petitioner seeks, but instead the purposes for which the writ of habeas corpus is made available." 48 Justice Harlan noted that habeas review had always been more limited in scope than direct review, largely because of "[t]he interest in leaving concluded litigation in a state of repose." ${ }^{49}$ This interest in finality, he concluded, counseled in favor of a general rule of nonretroactivity on collateral review. ${ }^{50}$

Justice Harlan suggested two exceptions to his rule of nonretroactivity on collateral review, both rooted in the historic function of the writ of habeas corpus. ${ }^{51}$ First, he would apply retroactively "[n]ew 'substantive due process' rules, that is, those that place . . . certain kinds of primary, private individual conduct beyond the power of the criminal law-making authority to proscribe." 52

44. Desist, 394 U.S. at 258.

45. Id. at 262 .

46. Id. at 259 (Harlan, J., dissenting); see also Mackey, 401 U.S. at 679 (Harlan, J., concurring in part and dissenting in part) ("If we do not resolve all cases before us on direct review in light of our best understanding of governing constitutional principles, it is difficult to see why we should so adjudicate any case at all.").

47. Mackey, 401 U.S. at 682 (Harlan, J., concurring in part and dissenting in part).

48. Id.

49. Id. at 683 .

50. Id. at 688-89; see also id. at 690 ("Finality in the criminal law is an end which must always be kept in plain view. . . . No one, not criminal defendants, not the judicial system, not society as a whole is benefited by a judgment providing a man shall tentatively go to jail today, but tomorrow and every day thereafter his continued incarceration shall be subject to fresh litigation on issues already resolved."). Justice Harlan also noted that, to the extent that the Court had expanded habeas review to "provide[] a quasi-appellate review function" in order to ensure that state courts "toe the constitutional mark," that interest would not be served by retroactively applying new rules on collateral review, since the rule (by definition) did not exist at the time the state court rendered its decision. $I d$. at 686-87.

51. Id. at 688-89.

52. Id. at 692. In Part IV, infra, we provide a detailed analysis of the historical and doctrinal 
Justice Harlan noted that the writ had historically been available for petitioners seeking to argue that the statute under which they were convicted was unconstitutional. ${ }^{53}$ Such situations "represent[] the clearest instance where finality interests should yield" because (1) "[t] here is little societal interest in permitting the criminal process to rest at a point where it ought properly never to repose" and (2) granting the writ on substantive grounds does not necessitate a costly and time-consuming retrial, as would granting it on procedural grounds. ${ }^{54}$ Second, Justice Harlan opined that the writ should be available for petitioners claiming that they were tried without procedural protections, such as the right to counsel articulated in Gideon, that are "implicit in the concept of ordered liberty." 55

\section{B. The Harlan Approach Prevails: Griffith and Teague}

1. Griffith: New Rules Apply Retroactively to All Cases on Direct Review.-In Griffith v. Kentucky, ${ }^{56}$ the Court considered whether the rule announced in Batson v. Kentucky ${ }^{57}$ applied retroactively to cases not yet final on direct review as of the date of the decision. ${ }^{58}$ Jettisoning the retroactivity analysis set forth in Linkletter and Stovall, the Court adopted Justice Harlan's proposal that new rules should always apply to cases pending on direct review. ${ }^{59}$ Any other rule, the Court determined, would "violate[] basic norms of constitutional adjudication," ${ }^{60}$ for two reasons. First, prospective rulemaking runs afoul of the "settled principle that th[e] Court adjudicates only 'cases' and "controversies." 61 Second, failure to apply new rules to cases pending on direct review creates the possibility that similarly situated defendants will be treated unequally. $^{62}$ Thus, the Court determined that Batson, and all subsequent decisions that established new constitutional rules of criminal law, would apply retroactively to defendants whose convictions had not yet become final as of the time of the decision announcing the new rule. ${ }^{63}$

underpinnings of Justice Harlan's proposed exception for "“substantive due process' rules."

53. $I d$. at $692-93$.

54. Id. at 693 .

55. Id. at 692-93 (quoting Palko v. Connecticut, 302 U.S. 319, 325 (1937)).

56. Griffith v. Kentucky, 479 U.S. 314 (1987).

57. Batson v. Kentucky, 476 U.S. 79 (1986).

58. In Batson, the Court held that a defendant can make a prima facie case of unconstitutional discrimination by showing that he is a member of a cognizable racial group, that the prosecutor exercised peremptory challenges to remove members of that group from the venire, and that other circumstances raised an inference that the prosecutor had excluded those members on the basis of their race. $I d$. at 96.

59. Griffith, 479 U.S. at 322.

60. $I d$.

61. Id. (citing U.S. CONST. art. III, § 2).

62. Id. at 323 .

63. Id. at 326-28. 
2. Teague: New Rules Do Not Apply Retroactively to Cases on Collateral Review.-Two years later, the Court completed its adoption of Justice Harlan's view by holding in Teague $v$. Lane that new rules generally do not apply retroactively to cases on collateral review. ${ }^{64}$ The Teague decision arose out of a state prisoner's challenge to his conviction based on the racial composition of his petit jury and the prosecutor's use of peremptory challenges to AfricanAmerican jurors. The petitioner contended that the prosecutor's use of peremptory challenges of African-Americans denied him the right to be tried by a jury that was representative of the community. In making this argument, he relied principally on two Supreme Court decisions: Taylor v. Louisiana, in which the Court held that the Sixth Amendment requires that the jury venire represent a "fair cross section of the community," Court detailed the showing that a defendant must make to establish that the prosecutor exercised peremptory challenges in a discriminatory manner. ${ }^{66}$ The petitioner's conviction had become final after Taylor but before Batson.

A plurality of the Court held that the petitioner could not rely on Batson because it did not apply retroactively to cases on collateral review. ${ }^{67}$ The Court also rejected the petitioner's argument that Taylor should be extended to dictate that the "fair cross section requirement" apply, not only to the venire, but to the petit jury as well. ${ }^{68}$ In doing so, the Court sought to clarify its retroactivity jurisprudence. This approach to retroactivity has since gained acceptance from a majority of the Court and still states the law today. ${ }^{69}$

The Court first defined a "new rule" as one that "breaks new ground or imposes a new obligation on the States or the Federal Government." "T0 "To put it differently, a case announces a new rule if the result was not dictated by precedent existing at the time the defendant's conviction became final." ${ }^{\prime 71}$ It then adopted, with a few relatively minor modifications, the approach to retroactivity advocated by Justice Harlan in his opinion in Mackey. ${ }^{72}$

As noted above, that approach is premised on a critical distinction between direct and collateral review. Teague reaffirmed Griffith's holding that a prisoner challenging his conviction on direct review is entitled to the benefit of any rule announced before his conviction becomes final, "with no exception for cases in which the new rule constitutes a "clear break' with the past." ${ }^{\text {73 }}$ In contrast, on

64. Teague v. Lane, 489 U.S. 288 (1989) (plurality opinion).

65. Taylor v. Louisiana, 419 U.S. 522 (1975).

66. Batson v. Kentucky, 476 U.S. 79 (1986).

67. Teague, 489 U.S. at 295-96.

68. Id. at 299.

69. See, e.g., Greene v. Fisher, 132 S. Ct. 38, 44 (2011) (citing Penry v. Lynaugh, 492 U.S. 302, 313 (1989)).

70. Teague, 489 U.S. at 301.

71. Id. (emphasis in original).

72. Mackey v. United States, 401 U.S. 667, 679 (1969) (Harlan, J., concurring in part and dissenting in part).

73. Teague, 489 U.S. at 304-05 (quoting Griffith v. Kentucky, 479 U.S. 314, 328 (1987)). 
collateral review, a federal habeas court must generally "apply the law prevailing at the time [the] conviction became final." 74 This distinction between direct review and collateral review is justified, explained the Teague Court, because on collateral review the interest in the finality of convictions generally outweighs "the competing interest in readjudicating convictions according to all legal standards in effect when a habeas petition is filed." 75

The Teague Court, echoing Justice Harlan, articulated two exceptions to the general principle that new rules do not apply retroactively to cases on collateral review. "First, a new rule should be applied retroactively if it places 'certain kinds of primary, private individual conduct beyond the power of the criminal law to proscribe." 76 Such "substantive rules" now include not only "primary conduct" rules, but also those that "narrow the scope of a criminal statute by interpreting its terms ... a as well as constitutional determinations that place particular . . . persons covered by the statute beyond the State's power to punish." 77 The Court has subsequently clarified that Teague's bar on the retroactive application of new rules on collateral review applies only to procedural rules. ${ }^{78}$ Hence, new substantive rules do not fall within an "exception" to Teague; instead, they are simply not subject to the Teague bar.

Second, a new rule is retroactively applicable if it is a "watershed rule[] of criminal procedure" that implicates the fundamental fairness of the trial and corrects a serious likelihood of an inaccurate conviction. ${ }^{79}$ The Teague Court suggested that this second exception was exceedingly narrow; indeed, it doubted "that many such components of basic due process have yet to emerge." Court's doubts on this score have proved well-founded, as it has rejected every claim thus far that a new procedural rule "satisfie[s] the requirements for watershed status." $" 81$

Applying these newly established principles, the Teague Court held that the petitioner could not rely on Taylor to obtain relief, because application of the fair cross section requirement to the petit jury would constitute a new rule that did

74. Id. at 306 (quoting Mackey, 401 U.S. at 698 (Harlan, J., concurring in part and dissenting in part)).

75. Id. (quoting Mackey, 401 U.S. at 682-83 (Harlan, J., concurring in part and dissenting in part)).

76. Id. at 307 (quoting Mackey, 401 U.S. at 692 (Harlan, J., concurring in part and dissenting in part)).

77. Schriro v. Summerlin, 542 U.S. 348, 351-52 (2004).

78. Id. at 352 .

79. Teague v. Lane, 489 U.S. 288, 311-14 (1989) (plurality opinion).

80. Teague, 489 U.S. at 313; see also Whorton v. Bockting, 549 U.S. 406, 418 (2007) (“[I]n the years since Teague, [the Court] ha[s] rejected every claim that a new rule satisfied the requirements for watershed status.").

81. Whorton, 549 U.S. at 418; accord State v. Tate, 130 So. 3d 829, 839 (La. 2013). The only rule the Court has identified that could satisfy the "watershed status" test is the rule of Gideon that counsel must be appointed for any indigent defendant charged with a felony. Whorton, 549 U.S. at 419 . 
not fall within either of the Teague exceptions. ${ }^{82}$ And the petitioner could not retroactively invoke Batson because that decision announced a new rule that had already been held non-retroactive to cases on collateral review. ${ }^{83}$

To summarize, Teague establishes the principle that a new rule - that is, one not "dictated" by prior precedent - does not apply retroactively on collateral review, unless (1) it places particular conduct or a particular class of person beyond the state's power to punish, or (2) it implicates fundamental fairness and significantly improves the accuracy of a criminal proceeding. ${ }^{84}$ The next section explores the significant changes to federal habeas law wrought by the AEDPA and the how those changes interact with the doctrine set forth in Teague.

\section{The Curious Relationship Between TEAGUE AND 28 U.S.C. $§ 2254(d)(1)$}

In 1996, Congress enacted the AEDPA, ${ }^{85}$ which amended 28 U.S.C. $\S$ 2254(d) to its current form. In passing the AEDPA, Congress sought "to ensure a level of deference to the determinations of state courts, . . . to curb delays, to prevent retrials on federal habeas, and to give effect to state convictions to the extent possible under law. ${ }^{" 86}$ In Williams v. Taylor, a fractured Court elaborated on the standard for determining whether a state court decision was "contrary to, or involved an unreasonable application of, clearly established Federal law, as determined by the Supreme Court of the United States." 87 Justice O'Connor, writing for the Court on this point, held as follows:

Under the "contrary to" clause, a federal habeas court may grant the writ if the state court arrives at a conclusion opposite to that reached by this Court on a question of law or if the state court decides a case differently than this Court has on a set of materially indistinguishable facts. Under the "unreasonable application" clause, a federal habeas court may grant the writ if the state court identifies the correct governing legal principle from this Court's decisions but unreasonably applies that principle to the facts of the prisoner's case. ${ }^{88}$

"[T]he phrase 'clearly established Federal law, as determined by the Supreme Court of the United States' . . refers to the holdings, as opposed to the dicta, of this Court's decisions as of the time of the relevant state-court decision." 89

82. Teague, 489 U.S. at 301, 311-16.

83. Id. at 295-96 (citing Allen v. Hardy, 478 U.S. 255, 258 (1986) (per curiam)).

84. See generally id. at 288.

85. Antiterrorism and Effective Death Penalty Act, Pub. L. No. 104-132, 110 Stat. 1214 (1996).

86. Williams v. Taylor, 529 U.S. 362, 386 (2000) (opinion of Stevens, J.) (internal quotation marks omitted).

87. Id. at 367.

88. Id. at 412-13 (opinion of O'Connor, J.).

89. Id. at 412. Despite some initial confusion on the issue, the Court has since confirmed that 
Justice O'Connor also made the following (somewhat confusing) observation about the relationship of $\S 2254(\mathrm{~d})(1)$ to the Teague non-retroactivity doctrine:

The "clearly established Federal law" phrase bears only a slight connection to our Teague jurisprudence. With one caveat, whatever would qualify as an old rule under our Teague jurisprudence will constitute "clearly established Federal law, as determined by the Supreme Court of the United States" under $\S 2254(d)(1) \ldots$ The one caveat, as the statutory language makes clear, is that $\S 2254(\mathrm{~d})(1)$ restricts the source of clearly established law to this Court's jurisprudence. ${ }^{90}$

As has been noted elsewhere, ${ }^{91}$ the first and second sentences of the abovequoted passage are hardly consistent; the second sentence would seem to suggest that the "clearly established Federal law" phrase bears a substantial, rather than slight, connection to the Teague doctrine. Whatever else the passage means, however, it makes clear that the definition of "clearly established federal law" is at least as broad as the definition of "old rules" under Teague and its progeny. ${ }^{92}$

Notably, and notwithstanding the confusing verbiage above, a majority of the Court rejected Justice Stevens' argument in dissent that $\S 2254(\mathrm{~d})(1)$ "codifies Teague" because the Teague doctrine was "the functional equivalent of a statutory provision commanding exclusive reliance on 'clearly established law." 93 The Court has since stated explicitly that the AEDPA did not codify Teague. ${ }^{94}$ But, by the same token, the Williams decision makes clear that the $\S$ 2254(d)(1) and Teague inquiries are at least partially congruent, in that "whatever would qualify as an old rule under our Teague jurisprudence will constitute clearly established Federal law." 95 And it is equally clear that the Teague analysis retains vitality even after the passage of the AEDPA. As the Court explained in Greene, "[t]he retroactivity rules that govern federal habeas review on the merits - which include Teague - are quite separate from the relitigation bar imposed by AEDPA; neither abrogates or qualifies the other." 96

The Court's per curiam opinion in Horn v. Banks, coupled with its question-

$\S 2254(\mathrm{~d})(1)$ "requires federal courts to 'focu[s] on what a state court knew and did,' and to measure state-court decisions 'against this Court's precedents as of the time the state court renders its decision," rather than the time at which the petitioner's conviction becomes final. Greene v. Fisher, 132 S. Ct. 38, 44 (2011) (alteration in original) (internal quotation marks omitted) (quoting Cullen v. Pinholster, 131 S. Ct. 1388, 1399 (2011)).

90. Id. at 412 .

91. FALLON ET AL., supra note 9, at 1260.

92. Id.

93. Williams v. Taylor, 529 U.S. 362, 379-80 (2000) (opinion of Stevens, J.) (internal quotation marks omitted).

94. Greene v. Fisher, 132 S. Ct. 38, 44 (2011).

95. Williams, 529 U.S. at 412 (internal quotation marks omitted).

96. Greene, 132 S. Ct. at 44; see also Day v. McDonough, 547 U.S. 198, 206 (2006) (citing Caspari v. Bolen, 510 U.S. 383, 389 (1994)); Horn v. Banks, 536 U.S. 266, 271 (2002). 
begging analysis in Danforth $v$. Minnesota,${ }^{97}$ shed perhaps the most light on Teague's relationship to the AEDPA. In Horn, the petitioner filed a state postconviction petition based on the new rule articulated in Mills v. Maryland, ${ }^{98}$ which the Pennsylvania Supreme Court rejected. ${ }^{99}$ In adjudicating the petitioner's claim, however, the state supreme court applied the new rule, although it was "skeptic[al] regarding the retroactivity of Mills." 100 With the benefit of a state-court adjudication on the merits rejecting his claim under the newly announced rule, the petitioner sought federal habeas relief, arguing that the state-court adjudication was contrary to the new rule. ${ }^{101}$ The Third Circuit declined to apply Teague (even though it had been argued by the State), reasoning that, because the Pennsylvania Supreme Court had applied the new rule, the only question was whether that court applied that rule correctly under $\S 2254(\mathrm{~d}) .^{102}$

The United States Supreme Court reversed, admonishing the Third Circuit that whether a petitioner satisfies $\S 2254$ (d) and whether he or she is entitled to habeas relief are distinct issues. ${ }^{103}$ Satisfaction of $\S 2254$ (d)'s standard of review is a necessary, but not sufficient, precondition to habeas relief; Teague is an independent hurdle that constrains a federal court's authority. ${ }^{104}$ Even if a statecourt adjudication is contrary to, or involved an unreasonable application of, clearly established federal law, a petitioner is not entitled to habeas relief unless he or she can avoid or overcome Teague. ${ }^{105}$ Horn appeared to leave open whether Teague was a constitutional requirement or a construction of the federal habeas statute and, if so, of what provision. ${ }^{106}$

In Danforth, the Court held that the states may determine the retroactivity of new rules of federal law using more generous standards than those articulated in

97. Danforth v. Minnesota, 552 U.S. 264 (2008). The most important questions left open by Danforth concern the constitutional status of the two Teague exceptions - whether they are a constitutional floor, binding on the states. See id. at 269 n.4 ("[T]his case does not present the questions whether States are required to apply 'watershed' rules in state post-conviction proceedings ....”). For many of the reasons articulated in this article, we believe that they are.

98. Mills v. Maryland, 486 U.S. 367 (1988) (holding that a state may not constitutionally require a jury to unanimously agree on the existence of a particular mitigating circumstance before it can consider that circumstance in its sentencing determination in a capital case).

99. Horn, 536 U.S. at 268-69.

100. Id. at 269.

101. Id.

102. Id.

103. Id. at 272 .

104. Id.

105. Id. ("While it is of course a necessary prerequisite to federal habeas relief that a prisoner satisfy the AEDPA standard of review set forth in 28 U.S.C. $§ 2254$ (d) . . . none of our postAEDPA cases have suggested that a writ of habeas corpus should automatically issue if a petitioner satisfies the AEDPA standard, or that AEDPA relieves courts from the responsibility of addressing properly raised Teague arguments.").

106. See generally id. at 266. 
Teague. ${ }^{107}$ In doing so, the Court clarified that its Teague jurisprudence-except perhaps the constitutional necessity of the two Teague exceptions ${ }^{108}$ - is based on a construction of 28 U.S.C. $\$ 2243$, which directs the federal courts to dispose of habeas petitions "as law and justice require." 109 Citing to cases in which the Court had "adjust[ed] the scope of the writ in accordance with equitable and prudential considerations," "110 the Court concluded that "Teague is plainly grounded in this authority, as the opinion expressly situated the rule it announced in this line of cases adjusting the scope of federal habeas relief in accordance with equitable and prudential considerations." "11

Teague, like $\S 2254(\mathrm{~d})$ where applicable, is thus an independent statutorylike limitation on the federal (but not state) courts' authority to grant habeas relief-satisfying Teague is a necessary, but not sufficient, condition to relief. In practice, Horn and Danforth operate as follows: First a petitioner must demonstrate that a federal court is authorized to grant a writ of habeas corpus under Teague, if the state properly raises the argument. It is immaterial that a state court, in a post-conviction proceeding, adjudicated the petitioner's claim in light of the later-developed rule because the Teague bar exists in reference to the time the petitioner's conviction becomes final on direct review, not to the time the state court adjudicates the petitioner's claim on the merits. ${ }^{12}$ Then, second, once the federal court determines that Teague does not bar it from issuing the writ, the petitioner must demonstrate that relief is not separately barred by $\S$ 2254(d), if the state court adjudicated his or her claim on the merits. ${ }^{113}$ It is the relationship between these two independent bars with which we are concerned.

Section 2254(d)(1), unlike the Teague non-retroactivity doctrine, does not set forth an exception for substantive rules of criminal law. Query whether a petitioner who is subject to $\S 2254(\mathrm{~d})(1)$ may rely on a new rule that fits within that Teague exception. In other words, do both of the independent bars identified above allow for at least the retroactive application of substantive rules on collateral review? This question-ostensibly a standard, if rather complex, question of statutory construction-obviously has significant practical importance for those petitioners who wish to invoke a Supreme Court decision that came down after their conviction became final. But the issue is important along another dimension as well: Lurking in the background of the statutory analysis are significant constitutional questions about Congress's power to limit the scope of the Great Writ.

107. Danforth v. Minnesota, 552 U.S. 264, 266 (2008).

108. See supra note 106.

109. Danforth, 552 U.S. at 278.

110. Id. (citing Brecht v. Abrahamson, 507 U.S. 619 (1993) (harmless-error standard); McCleskey v. Zant, 499 U.S. 467 (abuse-of-the-writ bar to relief); Wainwright v. Sykes, 433 U.S. 72 (1977) (procedural default); Stone v. Powell, 428 U.S. 465 (1976) (cognizability of Fourth Amendment claims).

111. Id.

112. See generally Horn, 536 U.S. at 266; Danforth, 522 U.S. at 264.

113. See generally Horn, 536 U.S. at 266; Danforth, 522 U.S. at 264. 
Suppose, for example, that a state court sentences a defendant to death in 2020. The defendant appeals his conviction through the state courts, arguing that capital punishment is unconstitutional. The state courts all reject that argument, and the defendant's conviction becomes final on direct review. Then, suppose that, two years later, the United States Supreme Court holds that the death penalty is unconstitutional. If $\S 2254(\mathrm{~d})(1)$ does not allow for the retroactive application of new substantive rules, then a federal habeas court is powerless to stop the state from executing the prisoner, notwithstanding the Supreme Court's holding that it is unconstitutional to do so. This result raises serious questions about the constitutionality of such a construction of the statute. ${ }^{114}$

But, despite its importance, this issue of statutory construction has received relatively little attention in both the case law and the literature. The opinions to address the question have, for the most part, either resolved it in conclusory fashion ${ }^{115}$ or noted the split of authority on the question and declined to take a position. ${ }^{116}$ Few articles have provided any analysis of the issue save for noting that the Court has left it unresolved. ${ }^{117}$

114. See, e.g., Muth v. Frank, 412 F.3d 808, 817 (7th Cir. 2005) (suggesting that the U.S. Supreme Court's holding in Lawrence v. Texas, 539 U.S. 558 (2003), that States may not constitutionally criminalize sodomy between persons of the same sex must apply retroactively to cases on habeas review because "[i]f it would be unconstitutional to punish a person for an act that cannot be subject to criminal penalties it is no less unconstitutional to keep a person in prison for committing the same act." (citing Mackey v. United States, 401 U.S. 667, 693 (1971) (Harlan, J., concurring in part and dissenting in part))); see also infra Part V.

115. See, e.g., Bockting v. Bayer, 399 F.3d 1010, 1021 (9th Cir. 2005), rev'd on other grounds sub. nom Whorton v. Bockting, 549 U.S. 406 (2007); Murillo v. Frank, 402 F.3d 786, 789 (7th Cir. 2005); Cockerham v. Cain, 283 F.3d 657, 660-61 (5th Cir. 2002) (citing Williams v. Cain, 229 F.3d 468 (5th Cir. 2000)); Ramdass v. Angelone, 187 F.3d 396, 406 n.4 (4th Cir. 1999), aff'd in part, 530 U.S. 156 (2000).

In Danforth v. Crist, the Eighth Circuit addressed and rejected the petitioner's argument that the new rule upon which he wished to rely fell within one of the Teague exceptions, apparently assuming that if it did, $\S 2254$ (d)(1) would not bar relief. Danforth v. Crist, 624 F.3d 915, 918-21 (8th Cir. 2010). To similar effect are Blintz v. Bertrand, 403 F.3d 859, 864-67 (7th Cir. 2005) and Lewis v. Johnson, 359 F.3d 646, 653-54 (3d Cir. 2004).

116. See Grossman v. McDonough, 466 F.3d 1325, 1341 n.13 (11th Cir. 2006); Mungo v. Duncan, 393 F.3d 327, 334-35 (2d Cir. 2004); Thompson v. Roy, No. 13-CV-1524, 2014 WL 1234498, at *8 n.2 (D. Minn. 2014).

117. See, e.g., FAllon ET AL., supra note 9, at 1264; RANDY HERTZ \& JAMES LiEBMAN, Federal Habeas Corpus Practice and Procedure $\S 32.3$ (2011) (noting the split of authority); Brian R. MEAns, Postconviction Remedies $§ 26: 23$ (2013) (same); $c f$. Adam N. Steinman, Reconceptualizing Federal Habeas Corpus for State Prisoners: How Should AEDPA's Standard of Review Operate After Williams v. Taylor?, 2001 WIS. L. REV. 1493, 1538-39 (identifying the issue); Tung Yin, A Better Mousetrap: Procedural Default as a Retroactivity Alternative to Teague v. Lane and the Antiterrorism and Effective Death Penalty Act of 1996, 25 AM. J. CRIM. L. 203, 223 (1998) ("If the Act does codify Teague, it does so without mention of Teague's two exceptions. It may be that Congress understood the exceptions to be significant enough that it is per se 
The most likely explanations for this apparent incongruity are twofold. First, the Teague "exceptions" are exceedingly narrow. A court can almost always sidestep the question of whether $\S 2254(\mathrm{~d})(1)$ incorporates either of the Teague exceptions by holding that, even assuming arguendo that it does, the petitioner is not entitled to relief because the rule he has invoked is neither substantive nor a watershed rule of criminal procedure. ${ }^{18}$

The second, more important, reason is that a claim under Teague must traverse a procedural thicket before the $\S 2254(\mathrm{~d})$ issue arises. The exhaustion requirement is likely the most important of the procedural obstacles to a Teague claim. Section 2254(c) codifies the common-law rule that a petitioner must exhaust his or her remedies in state court before bringing a federal habeas claim. ${ }^{119}$ Section 2254(c) requires a petitioner to give the state courts a fair opportunity to address a federal claim, whether on direct or post-conviction review, before his or her claim is cognizable on federal habeas. ${ }^{120}$ The

unreasonable for the prisoner not to be released if he raises a claim that would fall into either exception. Or perhaps Congress intended to ignore the exceptions."). Means, in a different section of his treatise, states conclusorily that $\S 2254(\mathrm{~d})(1)$ does not incorporate the Teague exceptions, but offers no analysis of the issue. MEANS, supra, $\S 26: 20$.

The two most in-depth analyses of the issue in the literature are found in student notes published shortly after the enactment of the AEDPA. See Sharad Sushil Khandelwal, Note, The Path to Habeas Corpus Narrows: Interpreting 28 U.S.C. $\$ 2254($ d)(1), 96 MICH. L. REV. 434 (1997); Note, Rewriting the Great Writ: Standards of Review for Habeas Corpus Under the New 28 U.S.C. \& 2254, 110 HARV. L. REV. 1868 (1997) [hereinafter Rewriting the Great Writ]. Khandelwal argues in a footnote that 2254(d)(1) codified the Teague exceptions because (1) Congress provided for retroactivity elsewhere in the AEDPA and so must have meant to provide for it in 2254(d)(1), in order that the other retroactivity provisions would still have meaning; and (2) reading 2254(d)(1) to eliminate the Teague exceptions would raise constitutional concerns. Khandelwal, supra, at $440 \mathrm{n} .45$. (Khandelwal's broader thesis - that $§ 2254(\mathrm{~d})(1)$ codified Teague in its entirety - has been clearly rejected by the U.S. Supreme Court. See supra notes 102-05 and accompanying text.) The analysis in Rewriting the Great Writ rests entirely on the constitutional avoidance canon, arguing that $\S 2254(\mathrm{~d})(1)$ should be read to incorporate the Teague exceptions because a contrary interpretation would constitute a serious infringement on the constitutional right to due process. Rewriting the Great Writ, supra, at 1884-85.

118. See Khandelwal, supra note 117, at 440 n.45. For example, in Whorton, the U.S. Supreme Court granted certiorari to decide two questions: first, whether the holding of Crawford v. Washington, 541 U.S. 36 (2004) - that the Confrontation Clause mandates that criminal defendants have an opportunity to cross-examine any witness who renders testimonial statements against them-applies retroactively to cases on collateral review under Teague; and second, whether $\S 2254(d)$ incorporates Teague's exceptions to non-retroactivity. See generally Whorton, 549 U.S. at 409. The Court found it unnecessary to decide the second question because it answered the first question in the negative. Whorton, 549 U.S. at 421. Similarly, in Thompson v. Roy, a Minnesota district court avoided the question by holding that the rule set forth in Miller does not fall within one of the Teague exceptions. Thompson, 2014 WL 1234498, at *8 n.2.

119. 28 U.S.C. $\S 2254$ (c) (2014).

120. Id. 
exhaustion requirement, coupled with the practice of most states to permit collateral review for Teague-exception claims, ${ }^{121}$ means that almost all such claims will be heard in state court. This, in turn, avoids the $\$ 2254(\mathrm{~d})$ issue. ${ }^{122}$ If the claim is adjudicated by a state court on post-conviction review under the newly-announced rule, the task of a federal court under $\S 2254$ (d) is to determine whether that state court decision, which applied the new rule, was contrary to or an unreasonable application of clearly established federal law at the time of the post-conviction proceeding. ${ }^{123}$

These procedural niceties significantly constrain the manner in which the issue under consideration can arise. But there are two ways in which the issue can still come up, notwithstanding the exhaustion requirement of $\S 2254$ (c). First, § 2254(d) could preclude federal habeas relief if (1) the state-court defendant anticipates a forthcoming new substantive rule of criminal law, like that announced in Lawrence v. Texas, ${ }^{124}$ Roper v. Simmons, ${ }^{125}$ or Atkins v. Virginia, ${ }^{126}$ and presents that claim to the state courts, thereby satisfying the exhaustion requirement; (2) the state court rejects the claim on the merits, based on then-existing Supreme Court precedent; (3) the Court later adopts the new rule, which is retroactive under Teague, while the petitioner is already in federal court seeking habeas relief; ${ }^{127}$ and (4) the state asserts $\S 2254(d)$ to preclude reconsideration in federal court. ${ }^{128}$

121. See Brief for Criminal Justice Legal Foundation as Amicus Curiae Supporting Petitioner, at 19, Whorton v. Bockting, 549 U.S. 406 (2007) (No. 05-595), 2006 WL 2066491, at*21-22 [hereinafter CJLF Whorton Brief].

122. As discussed above, it does not relieve a federal court of the requirement to conduct a Teague inquiry as a threshold matter, if Teague is raised by the State. See Horn v. Banks, 536 U.S. 266, 272 (2002).

123. See id. In such a case, the federal habeas court would first ask whether the rule was barred by Teague and then ask whether the state court decision applying the newly announced rule was contrary to or an unreasonable application of law. See id.

124. Lawrence v. Texas, 539 U.S. 558 (2003) (holding that Texas statute criminalizing private consensual sodomy violated the Due Process Clause).

125. Roper v. Simmons, 543 U.S. 551 (2005) (holding that the Eighth Amendment prohibits the execution of individuals who were minors at the time of their capital crimes).

126. Atkins v. Virginia, 536 U.S. 304 (2002) (holding that the Eighth Amendment prohibits the execution of mentally retarded persons).

127. There is no need for the petitioner to return to state court because his or her claim will already have been exhausted. See, e.g., O'Sullivan v. Boerckel, 526 U.S. 838, 844 (1999) ("[W]e have not interpreted exhaustion doctrine to require prisoners to file repetitive petitions."); Castille v. Peoples, 489 U.S. 346, 350 (1989); see also Brown v. Allen, 344 U.S. 443, 447 (1953) (construing same statutory language and concluding that " $[\mathrm{i}] \mathrm{t}$ is not necessary in such circumstances for the prisoner to ask the state for collateral relief, based on the same evidence and issues already decided by direct review with another petition for certiorari directed to th[e Supreme] Court").

128. This is essentially what occurred in Whorton. The petitioner argued that the introduction of evidence violated his Confrontation Clause rights. The state supreme court rejected the argument under then-prevailing Confrontation Clause jurisprudence. The petitioner, having exhausted the 
The second circumstance in which the issue under consideration could arise is a variation on the first: (1) the state-court defendant anticipates a forthcoming new substantive rule of criminal law, like that announced in Lawrence, Atkins, or Roper, and presents that claim to the state courts, thereby satisfying the exhaustion requirement; (2) the state court rejects the claim on the merits, based on then-existing Supreme Court precedent; (3) the Supreme Court later adopts the new rule, which is retroactive under Teague; (4) the state court refuses to reopen the case for a new decision on the merits on post-conviction review, based on a successive petition rule ${ }^{129}$ or a statute of limitations; ${ }^{130}$ and (5) the state asserts $\S 2254(d)$ to preclude reconsideration in federal court.

The Supreme Court's recent decision in Miller v. Alabama ${ }^{131}$ may force courts to squarely confront the curious relationship between Teague and $\S$ 2254(d)(1). Miller held that the Eighth Amendment prohibits a sentencing scheme that provides for mandatory life imprisonment without parole for a minor. ${ }^{132}$ There is, at the least, a strong argument that Miller announced a new substantive rule. We contend below that this argument is correct, in part; ${ }^{133}$ to the extent courts agree, and to the extent they face a habeas petition in one of the procedural postures explained above, they will have to face the difficult question of whether a petitioner subject to $\S 2254(\mathrm{~d})(1)$ may rely on a decision that is retroactive under Teague. The next section provides a discussion of the scope and historical pedigree of the substantive-rule exception and explains our view that Miller should be given limited retroactive effect.

\section{An ANALYSIS OF THE RETROACTIVITy OF MILLER V. ALABAMA}

For a court to reach the issue of whether $\S 2254(d)(1)$ allows for the retroactive application of substantive rules, it must find that a new constitutional rule of criminal law invoked by the petitioner is substantive under Teague and its progeny. Miller provides a likely, albeit limited, candidate for a decision

Confrontation Clause claim, sought federal habeas relief. At that point, the United States Supreme Court decided Crawford v. Washington, 541 U.S. 36 (2004), which arguably would have rendered the introduction of evidence at petitioner's trial unconstitutional. The Court ultimately did not consider the $\S 2254(\mathrm{~d})(1)$ issue because it held that Crawford was not retroactive under Teague. But the Ninth Circuit, which had concluded that Crawford was retroactive, was forced to address the $\S 2254$ (d) question. See Bockting v. Bayer, 399 F.3d 1010, 1021 (9th Cir. 2005).

129. See Cone v. Bell, 556 U.S. 449, 467 (2009) (holding successive litigation bar is not a procedural default and that a federal habeas court must "look through" to the last state court adjudication on the merits, if one exists).

130. This may raise a procedural default issue, although procedural default generally concerns only whether a claim has been presented at all. See id. at 466-68; see also id. at 472 (suggesting that where state court did, at some point, reach merits of claim that it subsequently held was barred, a federal court applies $\S 2254(d)$ ); Ylst v. Nunnemaker, 501 U.S. 797, 804 n.3 (1991).

131. Miller v. Alabama, 132 S. Ct. 2455 (2012).

132. Id. at 2475 .

133. See infra Part IV. 
announcing a substantive rule.

\section{A. Miller}

Miller concerned the constitutionality of two life-without-parole sentences imposed on fourteen-year-old offenders. ${ }^{134}$ Kuntrell Jackson's case arrived before the Court on state collateral review. ${ }^{135}$ Arkansas law permitted prosecutors to charge fourteen-year-olds as adults when they were alleged to have committed certain serious offenses, including felony murder. ${ }^{136}$ Jackson, fourteen at the time he participated in a robbery of a video store in which the store clerk was murdered, was charged as an adult and convicted. ${ }^{137}$ Pursuant to Arkansas's mandatory sentencing scheme, Jackson was sentenced to life imprisonment without the possibility of parole. ${ }^{138}$ Jackson did not challenge his sentence on appeal, but following the United States Supreme Court's decisions in Roper v. Simmons and Graham v. Florida, Jackson sought state habeas relief on the ground that a mandatory sentence of life without parole for a fourteenyear-old offender violated the Eighth Amendment. ${ }^{139}$ The state trial court rejected this argument, and the Arkansas Supreme Court affirmed the dismissal of Jackson's petition. ${ }^{140}$

Jackson's appeal was consolidated with the appeal of Evan Miller, whose case arrived before the Supreme Court on direct review. ${ }^{141}$ Like Jackson, Miller was fourteen at the time of his crime. ${ }^{142}$ Miller too was charged as an adult and was convicted of murder in the course of arson, a crime that, under Alabama law, carried with it a mandatory minimum punishment of life without the possibility of parole. ${ }^{143}$

In a five-to-four opinion, the Court held that a sentencing scheme that mandates life in prison without the possibility of parole for juvenile offenders violates the Eighth Amendment's proportionality principle. ${ }^{144}$ For the Court's majority, Miller lay at the intersection of two strands of precedent representing the Court's concern with proportionate punishment and individualized sentencing. ${ }^{145}$ The first of those strands adopted categorical bans on sentencing practices based on mismatches between the culpability of a class of offenders and

134. Miller, 132 S. Ct. at 2460.

135. Id. at 2461-63.

136. Id. at 2461.

137. Id.

138. Id.

139. Id. at 2461-63.

140. Id. at 2461.

141. Id. at 2462 .

142. Id.

143. Id. at 2462-63.

144. Id. at 2475.

145. Id. at 2461-62. 
the severity of a penalty. ${ }^{146}$ Of particular relevance, Roper and Graham barred sentencing practices for juvenile offenders because of their status as juveniles and their attendant diminished culpability. ${ }^{147}$ Roper barred capital punishment for children, and Graham barred the imposition of life without the possibility of parole for a juvenile non-homicide offender. ${ }^{148}$ Graham invoked the second line of precedent on which Miller relied - the Court's capital-sentencing jurisprudence-by observing that life without parole shares important characteristics with death sentences that are shared by no other sentences, namely, both sentences effect a "forfeiture that is irrevocable," an "especially harsh punishment for a juvenile." 149 The second strand of precedent prohibits the mandatory imposition of capital punishment and requires sentencing authorities to consider the individualized characteristics of defendants before sentencing a defendant to death. ${ }^{150}$

The Miller Court explained that "the confluence of these two lines of precedent leads to the conclusion that mandatory life-without-parole sentences for juveniles violate the Eighth Amendment." 151 To support this conclusion, the Court cast Roper and Graham at a high level of abstraction. ${ }^{152}$ The states' sentencing schemes contravened Graham's and Roper's "foundational principle: that imposition of a State's most severe penalties on juvenile offenders cannot proceed as though they were not children." ${ }^{53}$ And in the capital-sentencing context, which Graham likened to juvenile life without parole, the Court emphasized the requirement that a defendant have an opportunity to advance, and a judge or jury a chance to assess, mitigating factors, so that the state's harshest punishment is reserved only for the most culpable defendants. ${ }^{154}$ Thus, Graham and Roper and the Court's "individualized sentencing cases alike teach that in imposing a State's harshest penalties, a sentencer misses too much if he treats every child as an adult." 155

Miller garnered three strong dissents from four justices, each of whom took pains to emphasize that the majority's holding represented a break from precedent. Justice Roberts's dissent was most forceful in this conclusion, stating point-blank that "the Court's holding does not follow from Roper and Graham." 156 Justice Roberts focused on the sharp line Graham drew between homicide and other violent offenses: "The whole point of drawing a line

146. Id. at 2458 .

147. Id.

148. Id.

149. Graham v. Florida, 560 U.S. 48, 69-70 (2010).

150. Miller, 132 S. Ct. at 2463-64 (citing Lockett v. Ohio, 438 U.S. 586 (1978); Woodson v. North Carolina, 428 U.S. 280 (1976)).

151. Id. at 2464 .

152. Id.

153. Id. at 2466 .

154. Id. at 2467.

155. Id. at 2468 .

156. Id. at 2480 (Roberts, C.J., dissenting). 
between one issue and another," wrote Justice Roberts, "is to say that they are different and should be treated differently."157 "A case that expressly puts an issue in a different category from its own subject, draws a line between the two, and states that the two should not be compared, cannot fairly be said to control that issue." 158 Roper, Justice Roberts reasoned, provided even less support for the Court's holding because Roper set itself in a different category than Miller by "expressly invoking 'special' Eighth Amendment analysis for death penalty cases." 159 More important to this distinction was the fact that "Roper reasoned that the death penalty was not needed to deter juvenile murderers in part because 'life imprisonment without the possibility of parole was' available." 160 Roper, then, was a "classic bait and switch." ${ }^{161}$ Both Justice Thomas's dissent ${ }^{162}$ and Justice Alito's dissent ${ }^{163}$ were in agreement.

\section{B. Understanding the Substantive-Rule Exception}

Teague's basic rule is that new rules are not retroactive to cases on collateral review. ${ }^{164}$ Given the breadth with which "new" has been defined in this context, ${ }^{165}$ there is little dispute that Miller announced a new rule. It is sufficient to note that no court to consider Miller's retroactivity has found that it announces an old rule.

Teague's bar on the retroactive application of new rules is subject to two exceptions. ${ }^{166}$ Substantive rules of criminal law apply retroactively, as do " watershed rule[s] of criminal procedure' implicating the fundamental fairness and accuracy of the criminal proceeding $[\mathrm{s}] . " 167$ Before discussing whether Miller

157. Id. at 2481 .

158. $I d$.

159. Id. (quoting Roper v. Simmons, 543 U.S. 551, 568-69 (2005) (plurality opinion)).

160. Id. (quoting Roper, 543 U.S. at 572).

161. Id.

162. Id. at 2483 (Thomas, J., dissenting).

163. Id. at 2489 (Alito, J., dissenting).

164. Teague v. Lane, 489 U.S. 288, 299 (1989).

165. Academic commentary bemoaning the Court's expansive definition of "new" is legion. See, e.g., Bryant, supra note 15; Lyn S. Entzeroth, Reflections on Fifteen Years of the Teague v. Lane Retroactivity Paradigm: A Study of the Persistence, the Pervasiveness, and the Perversity of the Court's Doctrine, 35 N.M. L. REV. 161, 200-04, 212 (2005) (“As fifteen years of Teague have taught, the new rule doctrine is interpreted in such an extraordinarily broad manner that it is removed from the traditional concerns and concepts that gave rise to retroactivity limits in general and in the context of habeas corpus proceedings in particular."); Fallon \& Meltzer, supra note 26, at 1796; Linda Meyer, "Nothing We Say Matters": Teague and New Rules, 61 U. CHI. L. ReV. 423 (1994); Federal Courts Study CommitTeE, Working PAPERS AND SubCommitTeE RePorts (1990), available at www.fjc.gov/public/pdf.nsf/lookup/fcsvoll.pdf/\$file/fcscvoll.pdf, archived at http://perma.cc/LJN8-VLZ8.

166. See Teague, 489 U.S. at 288.

167. Whorton v. Bockting, 549 U.S. 406, 416 (2007) (alterations omitted) (quoting Saffle v. 
comes within one of these exceptions, it is important to note what Miller did not hold: Miller did not hold that the Eighth Amendment flatly prohibits life without parole for juveniles. ${ }^{168} \mathrm{Had}$ the Court done so, it would be quite easy to conclude that Miller was retroactive within the first Teague exception. ${ }^{169}$ Miller presents a much more difficult question - one which has sharply divided the courts to consider it. ${ }^{170}$

There is little analytical clarity to the proposed approaches to resolving the retroactivity issue, although commentators appear to agree that Miller should be held retroactive within one of Teague's exceptions. ${ }^{171}$ The most promising

Parks, 494 U.S. 484, 495 (1990)).

168. Miller, 132 S. Ct. at 2469 (“[W]e do not consider Jackson's and Miller's alternative argument that the Eighth Amendment requires a categorical bar on life without parole for juveniles, or at least for those 14 and younger.").

169. As will be discussed in greater detail below, a rule is substantive, and therefore retroactive, if, inter alia, it prohibits "a certain category of punishment for a class of defendants because of their status or offense." Penry v. Lynaugh, 492 U.S. 302, 330 (1989), overruled on other grounds by Atkins v. Virginia, 536 U.S. 304 (2002). A categorical prohibition on juvenile life without parole would prohibit a certain category of punishment (life without parole) for a certain class of defendants because of their status (juveniles).

170. Compare Illinois v. Davis, 6 N.E.3d 709 (Ill. 2014) (holding Miller retroactive), and Iowa v. Ragland, 836 N.W.2d 107 (Iowa 2013) (same), and Diatchenko v. Dist. Att'y for Suffolk Dist., 1 N.E.3d 270, 281 (Mass. 2013) (same), and Jones v. Mississippi, 122 So.3d 698 (Miss. 2013) (same), and Nebraska v. Mantich, 842 N.W.2d 716 (Neb. 2014) (same), with Louisiana v. Tate, 130 So.3d 829 (La. 2013) (holding Miller not retroactive), and Michigan v. Carp, Nos. 146478, 146819, 147428, 2014 WL 3174626, (Mich., July 8, 2014) (same), and Chambers v. Minnesota, 831 N.W.2d 311 (Minn. 2013) (same), and Pennsylvania v. Cunningham, 81 A.3d 1 (Pa. 2013) (same); cf. In re Morgan, 713 F.3d 1365 (11th Cir. 2013) (considering the analytically distinct but comparable question whether Miller is a new rule made retroactive on collateral review by the U.S. Supreme Court per 28 U.S.C. $\S 2255(\mathrm{~h})(2)$ and concluding it is not); Craig v. Cain, No. 12-30035, 2013 WL 69128 (5th Cir., Jan. 4, 2013) (same). Numerous other federal appellate courts have considered the issue in determining whether to authorize second or successive habeas petitions. Perhaps the most thoughtful consideration of Miller's retroactivity can be found in the various opinions respecting the denial of review en banc in In re Morgan. 717 F.3d 1186 (11 th Cir. 2013).

171. See Erwin Chemerinsky, Juvenile Life-Without Parole Case Means Courts Must Look at Mandatory Sentences, A.B.A. J. (Aug. 8, 2012), http://www.abajournal.com/news/article/ chemerinsky_juvenile_life-without-parole_case_means_courts_must_look_at_sen/, archived at http://perma.cc/3DCR-97FA ("My sense is that the Miller court did more than change procedures; it held that the government cannot constitutionally impose a punishment. As a substantive change in the law which puts matters outside the scope of the government's power, the holding should apply retroactively.”); Marhsa L. Levick \& Robert G. Schwartz, Practical Implications of Miller and Jackson Obtaining Relief in Court and Before the Parole Board, 31 J. L. \& INEQ. 369, 386 (2013) (concluding that Miller is a substantive rule of criminal law and a watershed rule of procedure); Molly F. Martinson, Negotiating Miller Madness: Why North Carolina Gets Juvenile Resentencing Right While Other States Drop the Ball, 91 N.C. L. REV. 2179, 2194-97 (2013) (same); Criminal Law-Juvenile Life Without Parole Sentences-Eleventh Circuit Holds That 
exception is for substantive rules of criminal law. Again, the Court has clarified that this is not really an "exception;" rather, rules of this sort "are more accurately characterized as substantive rules not subject to [Teague's] bar." 172 Nevertheless, for convenience, we refer to such rules as coming within the "substantive-rule exception." Every court of last review to hold Miller retroactive has done so under the aegis of the substantive-rule exception. ${ }^{173}$ What these courts do not agree upon, however, is a rationale. The difficulty lies not only with the complexity of Miller's holding, but also with the doctrine itself. ${ }^{174}$ As elsewhere, it is notoriously difficult to distinguish substantive and procedural rules. ${ }^{175}$ In the Erie Railroad Co. v. Tompkins context, courts have famously struggled to fashion an analytically satisfying line between the two. ${ }^{176}$ Miller presents precisely the same problem. ${ }^{177}$

As a matter of retroactivity doctrine, "[a] rule is substantive rather than procedural if it alters the range of conduct or the class of persons that the law punishes." 178 The difficulty with this definition - and the reason that courts of last resort have not come to a consensus as to whether Miller is substantive or

Miller Is Not Retroactive.-In Re Morgan, 713 F.3d 1365 (11th Cir.), Reh'g En Banc Denied, 717 F.3d 1186 (11th Cir. 2013), 127 HARV. L. REV. 1252, 1256 (2014) (concluding that, while the Eleventh Circuit's holding in In re Morgan that Miller is not retroactive is "doctrinally sound," the U.S. Supreme Court "should intervene.”); cf. Leading Cases, 126 HARV. L. REV. 276, 286 (2012) (concluding that "an implementation of procedural safeguards true to Miller's underlying premises amounts to something close to a de facto substantive holding ....").

172. Schriro v. Summerlin, 542 U.S. 348, 352 n.4 (2004). This characterization of substantive rules is not merely a matter of semantics; it has important implications for the statutory construction exercise that we undertake in infra Part V. See infra notes 414-17 and accompanying text.

173. See Davis, 6 N.E.3d at 722; Ragland, 836 N.W.2d at 117; Diatchenko, 1 N.E.3d at 281; Jones, 122 So. $3 \mathrm{~d}$ at 702; Mantich, 842 N.W.2d at 730. An analysis of whether Miller announced a watershed rule of criminal procedure is beyond the scope of this Article, although we believe it did not.

174. See, e.g., Katharine A. Ferguson, Note, The Clash of Ring v. Arizona and Teague v. Lane: An Illustration of the Inapplicability of Modern Habeas Retroactivity Jurisprudence in the Capital Sentencing Context, 85 B.U. L. REV. 1017, 1041 (2005) (critiquing the Court's current Teague jurisprudence in the context of rules with both substantive and procedural components). Making matters even more difficult is the fact that the majority opinion, Miller, reads like a studied effort to use precise but conflicting language from the Teague doctrine.

175. See, e.g., Shady Grove Orthopedics Ass'n v. Allstate Ins. Co., 559 U.S. 393, 414-15 (2010) (plurality opinion).

176. Erie R. Co. v. Tompkins, 304 U.S. 64 (1938).

177. Indeed, the Court has invoked its Erie jurisprudence in elaborating the definition of procedural rules for purposes of the Teague analysis. See Schriro, 542 U.S. at 353 ("Rules that allocate decisionmaking authority [between the jury and the judge] are prototypical procedural rules, a conclusion we have reached in numerous other contexts." (citing, inter alia, Gasperini v. Ctr. for Humanities, Inc., 518 U.S. 415, 426 (1996))).

178. Id. 
procedural $^{179}$ — is that the definition of "substantive," as the preceding quotation makes plain, is actually an amalgamation of subrules ${ }^{180}$ that have developed over time. The Court, as it does elsewhere, has acted like a common-law court, expanding the doctrine on a case-by-case basis. ${ }^{181}$

There are currently three, or possibly four, subrules comprising the definition of "substantive." First, a rule is substantive if it places primary, private conduct beyond the power of the state to proscribe. ${ }^{182}$ Second, a rule is substantive if it prohibits a certain category of punishment for a certain class of defendant because of their status or offense. ${ }^{183}$ Third, a rule is substantive if it narrows the scope of a criminal statute by interpreting its terms ${ }^{184}$ or, fourth, modifies the elements of the offense for which the individual was convicted or punished. ${ }^{185}$ "In contrast, rules that regulate only the manner of determining the defendant's culpability are procedural." 186

To properly understand the definition of substantive rules, one must first understand the origin of the substantive-rule exception and the functional considerations that motivated Justice Harlan to adopt it.

179. The U.S. Supreme Court has made clear that the states have an important role to play in the development of federal law in the Teague context. See Caspari v. Bolen, 510 U.S. 383, 395 (1994) ("Constitutional law is not the exclusive province of the federal courts, and in the Teague analysis the reasonable views of state courts are entitled to consideration along with those of federal courts."). Whether state courts are applying federal law in performing the Teague analysis is a more complex question since the Court's opinion in Danforth.

180. We borrow the term subrule from our wonderful Federal Courts professor, who was in large part an inspiration for this Article. See Richard H. Fallon, As-Applied and Facial Challenges and Third-Party Standing, 113 HARV. L. REV. 1321, 1331 (2000).

181. "Common law reasoning does not deduce results from previously established rules. Instead, it analogizes from one set of facts to another. Analogies are suggestive, but they are never logically compelling because any case will be somewhat like others and somewhat different — never identical." Meyer, supra note 165, at 425.

Common-law adjudication is not unfamiliar to the Court, even in the constitutional realm. As Professor Strauss compellingly argues, the Court is often in the business of common-law adjudication when it resolves constitutional questions. See generally David A. Strauss, Common Law Constitutional Interpretation, 63 U. CHI. L. REV. 877 (1996).

182. Saffle v. Parks, 494 U.S. 484, 494 (1990). This was the entirety of the substantive-rule exception as first articulated in Teague. See Teague v. Lane, 489 U.S. 288, 311 (1989) (citing Mackey v. U.S., 401 U.S. 667, 692 (1971) (Harlan, J., concurring in part and dissenting in part)). An example of this type of substantive rule would be the holding of Lawrence v. Texas, which prohibited the criminalization of sodomy. See generally Lawrence v. Texas, 539 U.S. 558 (2003). Miller plainly does not place primary private conduct beyond the power of the state to proscribe. Indeed, no court of last review has so held, and for good reason.

183. Penry v. Lynaugh, 492 U.S. 302, 330 (1989).

184. See Bousley v. United States, 523 U.S. 614, 620-21 (1998).

185. See Schriro v. Summerlin, 542 U.S. 348, 354 (2004). Obviously, there is a significant amount of potential overlap between these four subrules depending on the case.

186. Id. at 353 . 
1. The Common-Law Genesis of the Substantive-Rule Exception.-

a. Historical origins.- - In the Teague context, as elsewhere, what is past is prologue. Indeed, the historical province of the Great Writ is undeniably relevant, if not the guiding light, in interpreting its scope. ${ }^{187}$ The substantive-rule exception, as identified by Justice Harlan in Mackey and as adopted in Teague, is the direct descendant of the Court's original habeas jurisprudence. ${ }^{188}$

At its "historical core," the writ of habeas corpus functioned as a means of reviewing the legality of executive detention without judicial process. ${ }^{189}$ But from the earliest times, well predating the Republic, it was recognized that habeas corpus would lie to challenge a judicially authorized detention where the tribunal lacked jurisdiction of the matter. ${ }^{190}$ This is likely because a judgment entered without jurisdiction was considered void; ${ }^{191}$ consequently, detention pursuant to judicial process in an incompetent court amounted to executive detention with no process at all. But legal errors, even of constitutional dimension, were not cognizable on habeas once it was determined that the court

187. See INS v. St. Cyr, 533 U.S. 289, 301 (2001); Mackey v. United States, 401 U.S. 667, 692-93 (1971) (Harlan, J., concurring in part and dissenting in part) ("The relevant frame of reference, in other words, is not the purpose of the new rule whose benefit the petitioner seeks, but instead the purposes for which the writ of habeas corpus is made available."); Ex parte Watkins, 28 U.S. 193, 202-03 (1830); see also Note, Developments in the Law-Federal Habeas Corpus, 83 HARV. L. REV. 1042, 1045 (1970) [hereinafter Developments] ("In early opinions the Supreme Court indicated that while jurisdiction to issue the writ required statutory authorization, the purposes for which habeas corpus could be used were controlled by the common law.").

188. Teague, 489 U.S. at 311.

189. See St. Cyr, 533 U.S. at 301.

190. See Developments, supra note 187, at 1042-43 ("If a subject's liberty had been impaired by a tribunal which lacked competency in the matter, release would be ordered. But the inquiry upon habeas corpus into detentions under judicial order was limited: no relief would be granted if the return showed that the petitioner was imprisoned by the judgment of a court of competent jurisdiction."); Henry M. Hart, Foreword: The Time Chart of the Justices, The Supreme Court, 1958 Term, 73 HARV. L. REV. 84, 103-04 (1959). In Ex parte Watkins, the Court described the province of the writ as follows:

This writ is, as has been said, in the nature of a writ of error which brings up the body of the prisoner with the cause of commitment. The court can undoubtedly inquire into the sufficiency of that cause; but if it be the judgment of a court of competent jurisdiction, especially a judgment withdrawn by law from the revision of this court, is not that judgment in itself sufficient cause? Can the court, upon this writ, look beyond the judgment, and re-examine the charges on which it was rendered. A judgment, in its nature, concludes the subject on which it is rendered, and pronounces the law of the case. The judgment of a court of record whose jurisdiction is final, is as conclusive on all the world as the judgment of this court would be. It is as conclusive on this court as it is on other courts. It puts an end to inquiry concerning the fact, by deciding it.

Ex parte Watkins, 28 U.S. at 202-03.

191. See Ex parte Watkins, 28 U.S. at 197 ("All proceedings of a court beyond its jurisdiction are void."). 
possessed jurisdiction of the matter: ${ }^{192}$

There are other limitations of the jurisdiction [of federal courts to grant habeas relief,] however, arising from the nature and objects of the writ itself, as defined by the common law, from which its name and incidents are derived. It cannot be used as a mere writ of error. Mere error in the judgment or proceedings, under and by virtue of which a party is imprisoned, constitutes no ground for the issue of the writ. Hence, upon a return to a habeas corpus, that the prisoner is detained under a conviction and sentence by a court having jurisdiction of the cause, the general rule is, that he will be instantly remanded. No inquiry will be instituted into the regularity of the proceedings, unless, perhaps, where the court has cognizance by writ of error or appeal to review the judgment. ${ }^{193}$

As explained by Professor Hart: "[O]nce these inquiries were satisfied, the function of the writ, in the case of convicted prisoners, was at an end. If the rules distributing authority to make decisions had been complied with, in other words, an antecedent violation of the rules governing the decision to be made was immaterial." 194 The Court disclaimed any general power to review the judgments of inferior courts in criminal cases, as it would under a writ of error; the writ of habeas corpus existed only to test whether "the court below had any power to render the judgment by which the prisoner is held." 195

Following the Civil War, the Court softened its understanding of jurisdiction, for the first time allowing habeas petitioners to challenge that the statute under which they had been convicted was unconstitutional ${ }^{196}$ or that their detention was based on an illegally imposed sentence. ${ }^{197}$ Such errors were sufficiently close to jurisdictional errors-indeed, they were actually classified as jurisdictional errors - that they were held cognizable on habeas. The Court reasoned that challenges to the constitutionality of a sentence or punishment, like true jurisdictional challenges, were based on an assertion that the petitioner was suffering under a punishment the court lacked the competence or authority to impose. Ex parte Lange explained:

192. It should be recalled that the federal courts did not have statutory authority to issue a writ of habeas corpus to state prisoners until 1867, when Congress passed the Act of Feb. 5, 1867, ch. $28 \S 1,14$ Stat. 385. See Developments, supra note 187, at 1048 n.46 (discussing the special classes of cases in which the federal writ had been made available to state prisoners). Thus, questions concerning the scope of a federal court's authority to issue a writ to a state prisoner-and the comity concerns attendant to those questions - did not arise until that time. Moreover, it was not until the mid-twentieth century that the Eighth Amendment's Cruel and Unusual Punishments Clause was applied against the states. See Robinson v. California, 370 U.S. 660 (1962).

193. Ex parte Siebold, 100 U.S. 371, 375 (1879).

194. Hart, supra note 190, at 103-04.

195. E.g., Ex parte Lange, 85 U.S. 163, 166 (1873).

196. See, e.g., Ex parte Siebold, 100 U.S. at 371.

197. Lange, 85 U.S. 163; see also Danforth v. Minnesota, 552 U.S. 264, 272 n.6 (2008). 
It is no answer to this to say that the court had jurisdiction of the person of the prisoner, and of the offence under the statute. It by no means follows that these two facts make valid, however erroneous it may be, any judgment the court may render in such case. If a justice of the peace, having jurisdiction to fine for a misdemeanor, and with the party charged properly before him, should render a judgment that he be hung, it would simply be void. Why void? Because he had no power to render such a judgment. ${ }^{198}$

A court that acted beyond the scope of its constitutional authority to punish was without jurisdiction and the federal habeas statute authorized the federal courts to remedy such defects. ${ }^{199}$

Eventually, the Court expanded the scope of habeas relief by broadening the concept of jurisdiction beyond recognition, and by midway through the twentieth century it had jettisoned the concept of jurisdiction altogether, assuming plenary power to reexamine federal questions decided by the state courts. ${ }^{200}$ Nevertheless, the original understanding of jurisdiction - as concerning a court's competence or authority to detain or to punish - retained vitality. Even following the change in the scope of violations cognizable on habeas, "federal courts would never consider the merits of a constitutional claim ... if the petitioner had a fair opportunity to raise his arguments in the original criminal proceeding unless the petitioner attacked the constitutionality of the federal or state statute under which he had been convicted." 201 In other words, habeas relief was available to review an already-decided claim only to challenge underlying "jurisdictional" defects, as the phrase "jurisdictional" was used in the post-Civil War years.

$b$. The substantive-rule exception and post-Teague common-law rulemaking.-The substantive-rule exception is the successor to this legacy. In justifying the exception, Justice Harlan wrote:

New "substantive due process" rules, that is, those that place, as a matter of constitutional interpretation, certain kinds of primary, private individual conduct beyond the power of the criminal law-making authority to proscribe, must, in my view, be placed on a different footing .... [T] he writ has historically been available for attacking convictions on [substantive due process] grounds. This, I believe, is because it represents the clearest instance where finality interests should yield. There is little societal interest in permitting the criminal process to rest

198. Lange, 85 U.S. at 176.

199. See Developments, supra note 187, at 1047 ("It is an easy step to think of the trial court acting on the authority of a void law as wanting jurisdiction in the matter from the outset - hence habeas corpus would lie to release a prisoner of a court acting outside its competency.").

200. See id. at 1046-1055; Hart, supra note 190, at 103-08.

201. Mackey v. United States, 401 U.S. 667, 684 (1971) (Harlan, J., concurring in part and dissenting in part) (internal citations omitted). 
at a point where it ought properly never to repose. ${ }^{202}$

Justice Harlan cited as examples of substantive due process rules Ex parte Siebold,${ }^{203}$ Crowley v. Christensen, ${ }^{204}$ and Yick Wo v. Hopkins, ${ }^{205}$ cases in which the Court granted habeas relief on the ground that the state court lacked jurisdiction to detain the petitioner under a constitutionally infirm law. In each case, the Constitution, as a categorical matter, deprived the state of the authority to detain. ${ }^{206}$ Continued detention without jurisdiction, as a concept separate from the underlying constitutional violation, was violative of substantive due process. ${ }^{207}$ And a state's interest in finality could not overcome a constitutional guarantee to be free from punishment. ${ }^{208}$

In addition to the historical cases discussed above, Justice Harlan had four modern substantive due process rules "in mind": ${ }^{209}$

- Street v. New York, which held that the First Amendment prohibits a conviction for verbally casting contempt on the United States flag; ${ }^{210}$

- Stanley v. Georgia, which held that the First Amendment prohibits a conviction for the private possession of obscene material; ${ }^{211}$

- Griswold v. Connecticut, which held that the Constitution prohibits a conviction for the use of contraceptives; ${ }^{212}$ and

- Loving v. Virginia, which held that Equal Protection Clause prohibits a conviction for miscegenation. ${ }^{213}$

Teague, then, which adopted Justice Harlan's formulation in Mackey, established that a rule is substantive if it precludes the state from punishing private, individual conduct. ${ }^{214}$ This was in accord with the original scope of the writ as substantive due process challenges attacked the state's continuing jurisdiction to detain.

Anchored to this history, the Court has not deviated from a categorical

202. Id. at 692-93.

203. Ex parte Siebold, 100 U.S. 371 (1879).

204. Crowley v. Christensen, 137 U.S. 86 (1890).

205. Yick Wo v. Hopkins, 118 U.S. 356 (1886).

206. See generally Siebold, 100 U.S. at 317; Crowley, 137 U.S. at 86; Yick, 118 U.S. at 356.

207. See generally Siebold, 100 U.S. at 317; Crowley, 137 U.S. at 86; Yick, 118 U.S. at 356.

208. See generally Siebold, 100 U.S. at 317; Crowley, 137 U.S. at 86; Yick, 118 U.S. at 356.

209. See Mackey v. United States, 401 U.S. 667, 692 n.6 (1971).

210. Street v. New York, 394 U.S. 576, 594 (1969).

211. Stanley v. Georgia, 394 U.S. 557, 568 (1969).

212. Griswold v. Connecticut, 381 U.S. 479, 485 (1965).

213. Loving v. Virginia, 388 U.S. 1, 12 (1967).

214. Teague v. Lane, 489 U.S. 288, 307 (1989). 
understanding of the substantive-rule exception. ${ }^{215}$ What it has done, however, in the common-law tradition, is continued to expand the exception to cover additional categorical guarantees not initially contemplated. The scope of the writ, it must be recalled, is a matter of "the common law, from which its name and incidents are derived." ${ }^{16}$ Indeed, just four months after Teague, a majority of the court adopted Justice Harlan's approach and articulated the second substantive-law subrule, extending the doctrine to cover not only primary conduct but also rules categorically barring the imposition of certain sentences. ${ }^{217}$

Penry v. Lynaugh asked the Court to consider whether the Eighth Amendment prohibited the execution of mentally retarded individuals. ${ }^{218}$ Because the case was before the Court on collateral review, the Court began its analysis with Teague, for if the claim was Teague-barred there would be no need to answer the underlying constitutional question. ${ }^{219}$ The Court explained that "[a]1though Teague read th[e substantive rule] exception as focusing solely on new rules according constitutional protection to an actor's primary conduct, Justice Harlan did speak in terms of substantive categorical guarantees accorded by the Constitution, regardless of the procedures followed."220 In the Court's view, a rule that prohibited a certain category of punishment for a certain class of defendants was "analogous to" a rule placing private individual conduct beyond the state's power to proscribe. ${ }^{221}$ Both cases came within the ambit of the substantive-rule exception's underlying principle: "In both cases, the Constitution itself deprives the State of the power to impose a certain penalty."222 Accordingly, the Court held that "the first exception set forth in Teague should be understood to cover not only rules forbidding criminal punishment of certain primary conduct but also rules prohibiting a certain category of punishment for a class of defendants because of their status or offense." ${ }^{223}$ A categorical constriction of a court's competence to impose a punishment, the Penry subrule operated as a jurisdictional limitation within the historical purview of the writ

215. We use the word categorical as it is used in Penry - a rule is categorical if it per se prohibits a conviction or type of punishment, regardless of the procedures followed. Penry v. Lynaugh, 492 U.S. 302, 330-331 (1989), abrogated by Atkins v. Virginia, 536 U.S. 304 (2002).

216. Ex parte Siebold, 100 U.S. 371, 375 (1879).

217. Penry, 492 U.S. at 302.

218. Id.

219. Id. at 328-29.

220. Id. at 329 .

221. Id. at 330. Penry, of course, proved prescient. The Court subsequently held that the execution of mentally retarded persons was unconstitutional in Atkins v. Virginia, and the courts of appeals are unanimous in holding that Atkins is retroactive under this subrule.

222. Id.

223. Id. Penry represented another important extension of the doctrine from the non-capital to the capital-sentencing context. Penry has been thoroughly critiqued on the ground that it appeared to extend the doctrine in this manner-indeed, without the benefit of briefing or oral argument. See Fallon \& Meltzer, supra note 26, at 1818; Meyer, supra note 165, at 190-91. 
and was thus retroactively applicable. ${ }^{224}$ Indeed, Penry extended the substantiverule exception in accord with Ex parte Lange, which itself extended the concept of jurisdiction to cover challenges that the punishment received was beyond the court's competence to impose. ${ }^{225}$

In Bousley v. United States, ${ }^{226}$ the Court articulated the third substantive-law subrule covering decisions that narrow the scope of a criminal statute. ${ }^{227}$ Bousley pled guilty to using a firearm in violation of 18 U.S.C. $\$ 924(c)(1) .{ }^{228}$ Five years later, while Bousley sought federal habeas relief under 28 U.S.C. $\S 2255$, the Court decided Bailey v. United States, which held that $\S 924(\mathrm{c})(1)$ required the government to prove that the defendant actively employed the firearm. ${ }^{229}$ Bousley argued that in light of the intervening Bailey, his plea was not knowing and voluntary. ${ }^{230}$ The Court again extended the substantive-rule exception to the facts before it, reasoning that a decision narrowing the scope of a criminal statute was "like" a decision placing conduct beyond the power of the state to proscribe in that both necessarily carry a significant risk that a defendant stands convicted of an act that the law does not make criminal. ${ }^{231}$ Therefore, the Court explained, it would be "inconsistent with the doctrinal underpinnings of habeas review" to preclude a petitioner from relying on a rule narrowing the scope of a criminal statute. $^{232}$ Whereas Teague spoke of constitutional prohibitions on the punishment of certain primary conduct, the Bousley subrule applies to statutory prohibitions. ${ }^{233}$ In either case, the rule operates to deprive the state of continuing authority (and hence jurisdiction) to detain the petitioner.

Arguably, the fourth extension of the doctrine came in Schriro v. Summerlin, in which the Court, in dicta, expanded the Bousley subrule to cover sentencing. ${ }^{234}$ Schriro considered whether the rule announced in Ring v. Arizona ${ }^{235}$ was retroactive. ${ }^{236}$ Ring in turn concerned an Arizona statute that provided that a "'death sentence may not legally be imposed ... unless at least one aggravating factor is found to exist beyond a reasonable doubt." ${ }^{237}$ Ring held that because the aggravating factor operated as the " functional equivalent of an element of

224. Id.

225. Id.

226. Bousley v. United States, 523 U.S. 614, 620-21 (1998).

227. It is of note that Bousley arose in the context of a federal, not state, prosecution.

228. Id. at 616 .

229. Bailey v. United States, 516 U.S. 137, 150 (1995).

230. Bousley, 523 U.S. at 617-18.

231. Id. at 620 .

232. Id. at 621 .

233. It is unclear how relevant Bousley is to the question whether $\S 2254(d)(1)$ incorporates the substantive-rule exception because the U.S. Supreme Court has no authority to construe and narrow state criminal statutes other than to hold them unconstitutional.

234. Schriro v. Summerlin, 542 U.S. 348, 354 (2004).

235. Ring v. Arizona, 536 U.S. 584 (2002).

236. Id.

237. Id. at 597. 
a greater offense,' ... the Sixth Amendment require[ed] that they be found by a jury." 238 Schriro had argued that, like in Bousley, the Arizona statue modified the scope of the sentencing statue by requiring the presence of an element - the existence of an aggravating factor beyond a reasonable doubt. ${ }^{239}$ The Court rejected the comparison. ${ }^{240}$ Observing that "the range of conduct punished by death in Arizona was the same before Ring as after," the Court explained: "This Court's holding that, because Arizona has made a certain fact essential to the death penalty, that fact must be found by a jury, is not the same as this Court's making a certain fact essential to the death penalty. The former was a procedural holding; the latter would be substantive." ${ }^{241}$ Schriro, in effect, is the sentencing analogue to Bousley: where the Court makes a fact necessary to a conviction or punishment, the rule is substantive. ${ }^{242}$

With the full picture in view, a pattern emerges. In each of the modern cases, the Supreme Court has acted like a common-law tribunal, extending the doctrine of substantive rules to cover cases before it that would not necessarily have fallen within the previous definition. Mackey and Teague covered only primary conduct, but the Court broadened their reach to decisions prohibiting a category of punishment for a class of defendant because the situations were "analogous." ${ }^{243}$ Likewise, in Bousley and then in Schriro, the Court extended the doctrine to decisions narrowing criminal and sentencing statutes because the Court concluded that to hold otherwise would be "inconsistent with the doctrinal underpinnings of habeas review." 244 But the Court has never expanded the doctrine beyond its historical mooring. Historically, the writ of habeas corpus was only available to challenge a state's continuing authority to detain. The substantive-rule exception tracks the historical purpose of the writ, and it reaches no further than that categorical guarantee.

2. Functional Considerations.-The historical scope of the writ, followed fastidiously by the Court through the development of the substantive-rule exception, also makes functional sense in the retroactivity context. Justice Harlan acknowledged as much. ${ }^{245}$ An expansive retroactivity doctrine, he feared, would cause significant practical problems. States would be forced to "relitigate facts buried in the remote past through presentation of witnesses whose memories of the relevant events often have dimmed. This very act of trying stale facts may well, ironically, produce a second trial no more reliable as a matter of getting at the truth than the first." ${ }^{246}$ An overly expansive retroactivity doctrine

238. Id. at 609 (quoting Apprendi v. New Jersey, 530 U.S. 466 (2000)).

239. Schriro, 542 U.S. at 354.

240. Id.

241. Id.

242. See generally id.; Bousley v. United States, 523 U.S. 614 (1998).

243. Id. at 330.

244. Bousley, 523 U.S. at 621.

245. See Mackey v. United States, 401 U.S. 667 (1971) (Harlan, J., concurring in part and dissenting in part).

246. Id. at 691. 
would also threaten a significant drain on limited state resources. But, Justice Harlan explained, a substantive-rule exception grounded in "substantive due process" guarantees "entail[ed] none of the adverse collateral consequences of retrial." 247 Categorical rules, by their nature, do not require retrial of stale facts and the expenditure of significant state resources - the Constitution renders the petitioner innocent of the crime or punishment, period.

This point should not be overstated, though. Even with a categorical rule, resource-consuming litigation may ensue, for a petitioner may still be required to litigate the threshold question of entitlement to the rule. In the Atkins context, for example, subsequent litigation may be necessary for a petitioner to demonstrate that he or she is mentally retarded. Nevertheless, the societal costs of a complete re-trial or re-sentencing are generally greater than proving threshold eligibility for a retroactive rule. Moreover, in the mine-run of categorical rules, no subsequent litigation is necessary. An individual need not litigate his or her youth, for example, to obtain the benefit of Roper.

The potential evidentiary difficulties associated with Miller re-sentencing are pronounced. Miller instructed sentencers to consider "an offender's youth and attendant characteristics" before imposing life without the possibility of parole. ${ }^{248}$ As with youth itself, such evidence is fleeting. The most important piece of evidence will often be psychological examinations of the petitioner at the time the offense is committed. Post-hoc examinations cannot shed light on whether, at the time the juvenile was sentenced, his or her diminished culpability militated toward a more lenient sentence. Put another way, it will be difficult if not impossible for a sentencer to assess the offender's youth and attendant characteristics when the petitioner is no longer a youth. Unless a Miller resentencing is to function more like a parole determination, examining whether that person has demonstrated a capacity for change (as opposed to a true resentencing consistent with Miller), Miller, if retroactive, will present significant evidentiary difficulties.

3. Understanding the Substantive-Rule Exception.-Pre- and post-Teague history, as well as practical considerations, teach that the substantive-rule exception covers only categorical guarantees. While the Court may acknowledge new categorical guarantees, it has not expanded the doctrine to non-categorical rules. The substantive-rule exception should thus be understood as follows: A rule is substantive if a defendant, based on conduct or status, can no longer constitutionally be convicted or receive a certain punishment as a categorical matter - that is, regardless of the procedures followed. ${ }^{249}$ It admits of a simple, hypothetical test that focuses on the rule's effect on a petitioner's subsequent claim for relief: If the petitioner were given the benefit of the new rule, could his or her conviction or punishment stand as a matter of constitutional law? In other words, does the petitioner have a plausible claim that he or she is constitutionally innocent of the conviction or sentence? If the answer is yes, the rule is

247. Id. at 693.

248. Miller v. Alabama, 132 S. Ct. 2445, 2471 (2012).

249. Schriro v. Summerlin, 542 U.S. 348, 354 (2004). 
substantive. If no, the rule is procedural. ${ }^{250}$

Procedural rules, in contrast, should be understood to concern themselves not with whether a conviction or sentence may constitutionally be imposed, but with the proper mechanism to determine whether a conviction or sentence ought to be imposed. Procedural rules "merely raise the possibility that someone convicted with the use of the invalidated procedure might have been acquitted otherwise" and so possess only a "speculative connection to innocence." 251 Of critical import, procedural rules do not impose a constitutional bar that would operate to prevent the petitioner from being re-convicted or receive the same sentence. ${ }^{252}$

\section{Miller's Sentencing Requirement is Not Retroactive}

With the substantive-rule exception in focus, we proceed to assess Miller's retroactivity. Although many courts have found Miller to be retroactive, we agree with the minority of courts that Miller's sentencing requirement cannot be squared with the doctrine of substantive rules. ${ }^{253}$ Put simply, because Miller's sentencing requirement does not address a court's jurisdiction-i.e., its authority to punish - it does not fall within the exception for substantive rules of criminal law. ${ }^{254}$

250. Framed thus, the substantive-rule exception derives from an "innocence matters" conception of the primary role of habeas relief. See Fallon \& Meltzer, supra note 26, at 1816 ("From the innocence matters model came the notion that the prime function of habeas corpus is to secure individual freedom from unjustified confinement." (citation and internal quotation marks omitted). Importantly, the concept of "innocence" refers to actual innocence, as opposed to legal insufficiency. See Bousley v. United States, 523 U.S. 614, 623-624 (1998); Stone v. Powell, 428 U.S. 465, $491 \mathrm{n} .31$ (1976) ("Resort to habeas corpus, especially for purposes other than to assure that no innocent person suffers an unconstitutional loss of liberty, results in serious intrusions on values important to our system of government.").

The Court's "actual innocence" approach to the substantive-rule exception mirrors its habeas jurisprudence elsewhere, particularly in Stone, in which the Court held that a petitioner is not entitled to habeas relief on the ground that evidence was introduced in violation of the Fourth Amendment. Stone, 428 U.S. at 491 n.31. Unlike a substantive rule, "in the case of a typical Fourth Amendment claim, asserted on collateral attack, a convicted defendant is usually asking society to redetermine an issue that has no bearing on the basic justice of his incarceration." Id.

It is important not to overstate the reach of substantive rules. Not every petitioner who attempts to invoke a substantive rule will be entitled to relief under it. For example, following, Bousley, the petitioner was still required to prove that he did not actively use the weapon. Bousley, 523 U.S. at 624. Similarly, following Atkins, a petitioner's entitlement to habeas relief will depend on whether he or she can prove that he or she is mentally retarded. See Atkins v. Virginia, 536 U.S. 304 (2002). A substantive rule simply offers a defendant the chance to prove a constitutional defense to a conviction or punishment.

251. Schriro, 542 U.S. at 352.

252. Id. at 354 .

253. See, e.g., Penry v. Lynnaugh, 429 U.S. 302 (1989), abrogated by Atkins, 536 U.S. at 304.

254. Miller did not place primary conduct beyond the state's power to proscribe, so we do not 
1. Mandatory Life Imprisonment Without the Possibility of Parole Is Not a Category of Punishment.-By far the most common analytical approach to finding Miller retroactive is to hold that it prohibits a certain category of punishment for a class of defendant because of status or offense. ${ }^{255}$ The Penry Court, which first articulated this subrule, observed that if it "held, as a substantive matter, that the Eighth Amendment prohibits the execution of mentally retarded persons such as Penry regardless of the procedures followed, such a rule would fall under the first exception to the general rule of nonretroactivity and would be applicable to defendants on collateral review." 256

There are two versions of the argument that Miller is retroactive under Penry's subrule. The first is that the sum of Miller's dicta actually prohibits life imprisonment without the possibility of parole (a category of punishment) for juvenile offenders (a class of defendant). ${ }^{257}$ This argument is a nonstarter. While Miller did state that life imprisonment without the possibility of parole should be "uncommon," the Court also expressly stated that it did not "foreclose a sentencer's ability to make that judgment." 258 "Uncommon" is simply not the same as categorically unconstitutional.

The second argument is more sophisticated but ultimately doctrinally unconvincing. The nub of this argument is that mandatory life imprisonment without the possibility of parole is itself a category of punishment. ${ }^{259}$ But Penry makes clear that a "punishment" means a defendant's sentence (or conviction), regardless of the procedures followed. ${ }^{260}$ Life without the possibility of parole is the punishment, as used in Penry - whether or not it is mandatory concerns the procedures followed. It is nonsensical to say that Miller prohibited the imposition of mandatory life imprisonment without the possibility of parole regardless of the procedures followed because the mandatory imposition of a punishment is the procedure followed.

Mandatory life without parole is also not a "punishment" within the term's common usage. As explained by Judge Pryor in his opinion respecting the denial of rehearing en banc in In re Morgan:

Miller did not prohibit any category of punishment for juveniles. Punishment is defined as "[a] sanction - such as a fine, penalty, confinement, or loss of property, right, or privilege - assessed against a person who has violated the law." And Black's Law Dictionary cross-

consider that subrule further.

255. See Iowa v. Ragland, 836 N.W.2d 107, 115 (Iowa 2013); Diatchenko v. Dist. Att'y for Suffolk Dist., 1 N.E.3d 270, 281 (Mass. 2013); see also In re Morgan, 717 F.3d 1186, 1196 (11th Cir. 2013) (Barkett, J., dissenting from denial of rehearing en banc); Levick \& Schwartz, supra note 171, at 386; Martinson, supra note 171, at 2194.

256. Penry, 492 U.S. at 330.

257. See Martinson, supra note 171, at 2194.

258. Miller v. Alabama, 132 S. Ct. 2445, 2469 (2012).

259. See Martinson, supra note 171, at 2194-95.

260. Penry, 492 U.S. at 329-30. 
references "punishment" with "sentence," which is defined as "[t]he judgment that a court formally pronounces after finding a criminal defendant guilty; the punishment imposed on a criminal wrongdoer $<\mathrm{a}$ sentence of 20 years in prison $>$." Miller did not prohibit the punishment of life imprisonment without the possibility of parole for juvenile offenders, but only the mandatory procedure by which that punishment had been imposed .... . The attempt of [the] dissent to define the word "punishment" to include a "mandatory life sentence" is contrary to the ordinary legal meaning of that word. ${ }^{261}$

Language from Miller seems to speak directly to this point. The Court, in comparing Miller to Graham and Roper, wrote:

Our decision does not categorically bar a penalty for a class of offenders or type of crime - as, for example, we did in Roper or Graham. Instead, it mandates only that a sentencer follow a certain process - considering an offender's youth and attendant characteristics - before imposing a particular penalty. ${ }^{262}$

It is difficult to find a more precise match between the doctrinal test and the Court's own description of its holding.

The common understanding of the term punishment, and more importantly, the definition of punishment employed by Penry, forecloses the conclusion that a mandatory sentence is a category of punishment. Miller is not retroactive under the Penry subrule.

2. Miller Did Not Narrow State Sentencing Statutes. - Other courts have held that Miller is retroactive under the Bousley subrule. ${ }^{263}$ Bousley holds generally that "decisions that narrow the scope of a criminal statute by interpreting its terms" are substantive. ${ }^{264}$ The Mississippi Supreme Court, for example, held as follows:

Following Miller, Mississippi's current sentencing and parole statutes could not be followed in homicide cases involving juvenile defendants. Our sentencing scheme may be applied to juveniles only after applicable Miller characteristics and circumstances have been considered by the sentencing authority. As such, Miller modified our substantive law by narrowing its application for juveniles. ${ }^{265}$

This approach is problematic for two reasons. First, Miller did not modify

261. In re Morgan, 717 F.3d 1186, 1192 (11th Cir. 2013) (Barkett, J., dissenting from denial of rehearing en banc) (internal citations omitted).

262. Miller, 132 S. Ct. at 2471.

263. See Jones v. Mississippi, 122 So.3d 698, 702 (Miss. 2013); Nebraska v. Mantich, 842 N.W.2d 716, 730-31 (Neb. 2014).

264. Schriro v. Summerlin, 542 U.S. 348, 351 (2004).

265. Jones, 122 So. $3 \mathrm{~d}$ at 702. 
Mississippi's substantive law; it modified a sentencing scheme. ${ }^{266}$ Second, to conclude that a sentencing scheme constitutes substantive law overstates the doctrine's reach in a critical respect. Not every decision that narrows the reach of a statute is substantive. Consider Graham v. Collins. ${ }^{267}$ Graham, the habeas petitioner, had been sentenced to death pursuant to a Texas capital-sentencing statute that required the death penalty if the jury unanimously answered various "special issues." 268 Graham sought habeas relief, arguing that the sentencing statute's special issues framework precluded the jury from giving effect to mitigating evidence in violation of the Eighth and Fourteenth Amendments. ${ }^{269}$ Because the case arrived before the Court on collateral review, the Court first considered whether, even if the Constitution required the rule put forward by Graham, he was nevertheless Teague-barred from relying on it. ${ }^{270}$ Although the rule Graham sought would have, like Miller, invalidated a statute that required the imposition of a penalty because it foreclosed the sentencer's ability to consider mitigation evidence, the Court concluded that this "[p]lainly" would not be a substantive rule. ${ }^{271}$ While the rule would operate to invalidate the mandatory sentencing aspect of a state statute, it did not address a substantive categorical guarantee. ${ }^{272}$ Statutes regulating the manner in which a punishment is imposed, as opposed to statutes that prescribe certain punishments or offenses, are procedural. ${ }^{273}$ Accordingly, rules that narrow the scope of procedural statutes are procedural.

3. Miller Did Not Add an Element to Juvenile Life Without Parole Sentences.-Schriro v. Summerlin extended the Bousley subrule to cover decisions adding an element to an offense or punishment. ${ }^{274}$ But Miller did not add an element that must be found before life imprisonment without the possibility of parole may be imposed. While Miller requires the sentencing authority to consider a defendant's culpability, ${ }^{275}$ it does not require any particular finding be made. Moreover, even if Miller held that a defendant must cross a sufficient level of culpability for a sentence of life imprisonment without the possibility of parole to be imposed, the absence of culpability "is not an element of the sentence any more than sanity is an element of an offense." 276

266. As will be discussed, infra, Part IV.C.3, Miller's modification of state sentencing schemes did not add an element to an offense.

267. Graham v. Collins, 506 U.S. 461 (1993).

268. Id. at 464-65 (citing TeX. CODE CRIM. Pro. art. 37.071).

269. Id. at 463 .

270. $I d$.

271. Id. at 477 .

272. Id.

273. See, e.g., In re Morgan, 717 F.3d 1186, 1192 (11th Cir. 2013) (Barkett, J., dissenting from denial of rehearing en banc).

274. Schriro v. Summerlin, 542 U.S. 348, 354 (2004).

275. Miller v. Alabama, 132 S. Ct. 2445, 2475 (2012).

276. In re Johnson, 334 F.3d 403, 405 (5th Cir. 2003) (discussing the absence of mental retardation in Atkins). 
Non-culpability, like mental retardation in the Atkins context, is a constitutional defense that operates only to decrease the sentence to which the defendant is exposed. Its converse is not a fact that a state must prove before imposing a lifewithout-parole sentence. ${ }^{277}$

4. Expanding the Range of Sentencing Outcomes.-Perhaps the strongest argument for retroactivity calls for a significant expansion of the substantive-rule exception. The argument goes: Miller is retroactive despite the above because it expanded the range of sentencing outcomes available for juvenile homicide offenders. ${ }^{278}$ Whereas before Miller, states like Iowa and Mississippi permitted only a life-without-parole sentence for persons convicted of certain crimes, Miller operates to broaden the range of available punishments to a subset of individuals convicted of those crimes. ${ }^{279}$ This is undoubtedly a significant change to state law. Indeed, it is, for all intents and purposes, the converse of a rule prohibiting a penalty, which would be retroactive under Teague. The question is whether the same justifications supporting retroactivity for a decision narrowing the scope of sentencing outcomes support retroactivity for a decision broadening the scope of sentencing outcomes.

In our view, the answer is no. The critical difference between the two scenarios is that decisions narrowing the scope of sentencing outcomes operate as categorical guarantees, whereas decisions broadening the scope of outcomes do not. If the United States Supreme Court held it unconstitutional to impose life in prison without parole on a juvenile (an example of the former scenario), then any person who could show that she or he was a juvenile at the time of the offense would be entitled to relief - end of story. But, after Miller, an individual who can show that he or she was a juvenile at the time of the offense is not necessarily entitled to relief; he or she is simply entitled to a sentencing determination that takes into account a wider range of possible punishments. And only rulings abrogating a state's jurisdiction to punish-i.e., rules that categorically strip a state of authority-are substantive. Holding Miller retroactive because it expanded the scope of sentencing outcomes cannot be squared with the doctrine's historical origin, its post-Teague development, and the functional considerations identified by Justice Harlan. Importantly, allowing non-categorical rules to have retroactive effect will necessarily entail re-litigation of the underlying conviction or punishment, the outcome that the doctrine is

277. Also, for this reason, it would not run afoul of Apprendi v. New Jersey, 530 U.S. 466, 489 (2000), to place the burden of proving non-culpability on the defendant, nor would it run afoul of Ring to permit a court to make that determination. But see Chemerinsky, supra note 171. In the Atkins context, the overwhelming majority of courts have held that a state may place the burden of proving mental retardation on the defendant and that a judge may make that finding. See, e.g., Hill v. Humphrey, 662 F.3d 1335, 1360 (11th Cir. 2011) (en banc) (holding Georgia did not violate clearly established law by requiring defendant to prove mental retardation beyond a reasonable doubt); In re Johnson, 334 F.3d at 405 (holding that defendant does not have Sixth Amendment right to have jury determine mental retardation).

278. Miller, 132 S. Ct. at 2445.

279. Id. 
meant to avoid.

Moreover, the courts of appeals have uniformly rejected a similar argument in considering whether United States v. Booker ${ }^{280}$ is retroactive. Like Miller, Booker held that a mandatory sentencing regime was unconstitutional. ${ }^{281}$ Until Booker, the Federal Sentencing Guidelines were considered binding on federal courts under the Sentencing Reform Act. ${ }^{282}$ The Booker Court held that those guidelines were not mandatory, but instead, are merely a tool to guide district courts in their discretion. ${ }^{283}$ The effect of Booker, similar to that of Miller, was to expand the range of sentencing outcomes available to defendants-postBooker, federal district courts were permitted to vary above and below the guidelines. No federal court of appeals has considered this change to the district courts' sentencing authority to be substantive. ${ }^{284}$ Booker allocated decisionmaking authority between the Sentencing Commission and federal district courts and, as such, was a "prototypical procedural rule[]." 285

This analysis applies with equal force to Miller. To be sure, Booker arose under the Sixth Amendment, while Miller arose under the Eighth. ${ }^{286}$ But there is nothing doctrinally significant about the constitutional amendment that grounds a rule. And as discussed above, the substantive-rule exception concerns itself with a decision's effects, not its reasoning. ${ }^{287}$ The primary reason that Miller has been assessed somewhat differently than Booker is that Miller is a more specific decision. While Miller held invalid the mandatory imposition of a specific sentence to a specific category of offender, ${ }^{288}$ Booker held invalid the mandatory imposition of a sentencing range to any and all federal defendants. ${ }^{289}$ Nevertheless, Miller's effect, like Booker's, was to expand the range of sentencing outcomes available to criminal defendants within the rule's purview. As explained at length above, a rule expanding a court's sentencing authority is not a substantive rule. On its face, Miller is non-retroactive under Teague.

280. United States v. Booker, 543 U.S. 220 (2005).

281. Id. at 226 .

282. Id. at 233; see also id. at 220 n.2.

283. Id. at 245 .

284. See, e.g., United States v. Cruz, 423 F.3d 1119, 1120 (9th Cir. 2005) ("We now join every other circuit that has considered the question in holding that the rule announced by Booker does not meet any of the Teague exceptions, and thus does not operate retroactively.").

285. Id. (quoting Schriro v. Summerlin, 542 U.S. 348, 353 (2004)).

286. See Miller v. Alabama, 132 S. Ct. 2445, 2460 (2012); Booker, 543 U.S. at 226.

287. See supra Part IV.B.1.b. Indeed, the cases cited by Justice Harlan to ground the substantive-rule exception arose under a wide variety of constitutional provisions. See Mackey v. United States, 401 U.S. 667, 692 n.7 (1971) (Harlan, J., dissenting in part and concurring in part).

288. See Miller, 132 S. Ct. at 2460.

289. See Booker, 543 U.S. at 226. 


\section{Miller's Implicit Holding: Prohibiting Life Imprisonment Without Parole for Non-Culpable Juveniles}

The difficulty at this point is that the doctrine appears to countenance a gross unfairness. $^{290}$ Adults who have demonstrated a capacity for rehabilitation will be denied any chance to secure their release, even though Miller suggests that where an offender could have demonstrated a "capacity for change" he or she should not have been sentenced to life in prison. ${ }^{291}$ Even more unfair is the accident of timing present in all retroactivity cases. Had the petitioners at issue committed their crimes after June 2012, they would have had the opportunity to explain why they did not deserve to spend the rest of their lives in jail.

This section offers a narrow path through which to escape this unfairness, one consistent with both the doctrine and Miller. Best read, juveniles sentenced before Miller should be afforded the opportunity to prove that a life-withoutparole sentence cannot constitutionally be imposed upon them. That is, Miller has both a procedural component (detailed above) and a substantive component (detailed below). It may take a follow-on Supreme Court decision to recognize this constitutional right, but that constitutional right, whether inferred directly from Miller or subsequently articulated, will be retroactive. ${ }^{292}$ For convenience, we refer to this as Miller's implicit rule.

Miller's implicit rule inheres in its reasoning and flows from the precedents on which it relied. Miller is fundamentally a case about the proportionality principle. The proportionality principle, an Eighth Amendment sub-doctrine, generally prohibits a punishment that is not proportional to the culpability of the offender. ${ }^{293}$ Miller's holding was an application of this principle:

By requiring that all children convicted of homicide receive lifetime incarceration without possibility of parole, regardless of their age and age-related characteristics and the nature of their crimes, the mandatory sentencing schemes before us violate th[e] principle of proportionality, and so the Eighth Amendment's ban on cruel and unusual punishment. ${ }^{294}$

But a sentencing scheme, as a procedural matter, cannot violate the proportionality principle. ${ }^{295}$ Proportionality is a quality of a sentence, not a

290. See Chemerinsky, supra note 171.

291. Miller, 132 S. Ct. at 2460.

292. Because of the broad definition of new rules, we think courts will be forced to resort to retroactivity analysis even if the rule is acknowledged in a subsequent decision. That is, the rule is not compelled by Miller, although we believe it is the best reading of Miller. See Miller, $132 \mathrm{~S}$. Ct. at 2455.

293. Id. at 2463. The landmark case on the proportionality principle is Weems v. United States, in which the Court held "that it is a precept of justice that punishment for crime should be graduated and proportioned to offense." Weems v. United States, 217 U.S. 349, 367 (1910).

294. Miller, 132 S. Ct. at 2475.

295. See, e.g., id. (explaining that the punishment for a crime should be proportional to the offense). 
quality of a procedural mechanism for determining a sentence. For a mandatory sentencing scheme to violate the proportionality principle, it must be true that some of the resulting sentences are disproportionate and therefore unconstitutional. Thus, implicit in Miller is the fact that some sentences of life imprisonment without the possibility of parole for juvenile offenders are unconstitutional because the defendant lacks a sufficient level of culpability to receive the sentence. If this were not the case, the sentencing scheme at issue in Miller could not have violated the proportionality principle.

This conclusion also flows from the cases on which Miller relied. Miller borrowed its proportionality-principle reasoning primarily from Roper and Graham. ${ }^{296}$ Those cases established "that children are constitutionally different from adults for purposes of sentencing." have diminished culpability and greater prospects for reform ... 'they are less deserving of the most severe punishments."'298 Where Miller differed from Roper and Graham was the extent to which juvenile culpability rendered the sentences at issue unconstitutionally disproportionate. ${ }^{299}$ It is this difference that explains why Miller was couched in procedural terms while those cases were not.

In Roper, diminished juvenile culpability meant that no juvenile could receive a death sentence ${ }^{300}$-in other words, all juveniles are insufficiently culpable to receive that sentence. The same goes for Graham - all juveniles are insufficiently culpable to receive a life-without-parole sentence for non-homicide offenses. ${ }^{301}$ In Miller, however, the Court did not conclude that all juveniles are insufficiently culpable to receive a life-without-parole sentence — only that some of them are. For those who are insufficiently culpable, as in Roper and Graham, the Eighth Amendment proportionality principle prohibits a particular sentence as a categorical matter. ${ }^{302}$ For those who are sufficiently culpable, a life-withoutparole sentence is not constitutionally problematic. Thus, the Court did not "foreclose a sentencer's ability to" impose the punishment in question in all cases; it merely foreclosed that ability in cases where the juvenile's culpability falls below a threshold level. ${ }^{303}$ But because Miller did not identify a clean dividing line, a procedure was necessary to distinguish culpable from insufficiently culpable juvenile defendants. This gave rise to Miller's procedural holding. ${ }^{304}$

296. See generally Roper v. Simmons, 543 U.S. 551 (2005); Graham v. Florida, 560 U.S. 48 (2010).

297. Miller, 132 S. Ct. at 2464.

298. Id. (quoting Graham, 560 U.S. at 68).

299. Id. at 2461.

300. Roper, 543 U.S. at 568.

301. Graham, 560 U.S. at 74.

302. See generally U.S. CONST. amend. VII; Roper, 543 U.S. at 551; Graham, 560 U.S. at 48.

303. See generally U.S. CONST. amend. VII; Roper, 543 U.S. at 551; Graham, 560 U.S. at 48.

304. See Miller, 1302 S. Ct. at 2460. Miller may have taken a "proceduralist tack" because of the difficulty of drawing a bright line between sufficiently culpable and insufficiently culpable juveniles. Lockett v. Ohio (438 U.S. 586, 615 (1978) (Blackmun, J., concurring)). Indeed, because 
That Miller applied the proportionality principle distinguishes it in a critical respect from the other line of precedent on which it relied-the capitalsentencing cases. Those cases, unlike Miller, mandated sentencing procedures out of a concern for sentencing accuracy. Woodson v. North Carolina held that a statute mandating a death sentence for first-degree murder violated the Eighth Amendment, and relied on "the need for reliability in the determination that death is the appropriate punishment in a specific case," a need that arises because death is different than other sentences in its irrevocability. ${ }^{305}$ In other words, Woodson was concerned with enhancing the accuracy of capital-sentencing, not with constitutionally disproportionate sentencing outcomes. Lockett v. Ohio ${ }^{306}$ and Eddings v. Oklahoma ${ }^{307}$ followed suit. ${ }^{308}$ Those cases adopted sentencing procedures designed to enhance sentencing accuracy. ${ }^{309}$

Miller, however, was concerned not only with sentencing accuracy (i.e., whether a sentence should be imposed), but also with the categorical question of whether a sentence can constitutionally be imposed. ${ }^{310}$ The capital-sentencing cases are best understood as providing a procedural blueprint to protect the underlying constitutional right implicit in Miller. ${ }^{311}$ Expanding on the analysis in Roper and Graham, Miller implicitly identified that some juvenile-lifewithout-parole sentences are unconstitutional, no matter what process leads to their imposition. ${ }^{312}$ But because the Court was not willing to separate out a readily identifiable class of offender, the Court needed a procedure designed to safeguard the underlying right. Miller looked to the capital-sentencing cases, which relied on an entirely different rationale-procedural fairness, not proportionality - for a procedure. Roper and Graham guided the way to the right; Woodson, Lockett, and Eddings showed how to protect it. ${ }^{313}$

its holding was sufficient to decide the case, the Miller Court declined to consider where this line might lie. Miller, 132 S. Ct. at 2469. Miller, which was couched in procedural terms yet relied on the proportionality principle, makes clear that some juvenile-life-without-parole sentences are now unconstitutionally disproportionate. See generally id. at 2445.

305. Woodson v. North Carolina, 428 U.S. 280, 305 (1976).

306. Lockett v. Ohio, 438 U.S. 586, 605 (1978) (plurality opinion).

307. Eddings v. Oklahoma, 455 U.S. 104, 117 (1982). But see id. at 600 n.9.

308. See also Sumner v. Shuman, 483 U.S. 66 (1987).

309. Lockett and Eddings have since received a proportionality-principle gloss. In Penry, the Court stated that underlying those cases was "the principle that the punishment should be directly related to the personal culpability of the criminal defendant." Penry v. Lynaugh, 492 U.S. 302, 319 (1989), abrogated by Atkins v. Virginia, 536 U.S. 304 (2002). Nevertheless, those decisions do not suggest, as does Miller, that there exists a threshold below which a certain sentence would be unconstitutionally disproportionate.

310. Miller v. Alabama, 132 S. Ct. 2445, 2460 (2012).

311. See generally id. at 2445.

312. Id. at 2460.

313. See generally Graham v. Florida, 560 U.S. 48 (2010); Roper v. Simmons, 543 U.S. 551 (2005); Eddings v. Oklahoma, 455 U.S. 104 (1982); Lockett v. Ohio, 438 U.S. at 586 (1978) (plurality opinion); Woodson v. North Carolina, 428 U.S. 280 (1976). 
Miller's syllogism can thus be understood as follows: (1) the Eighth Amendment requires that a punishment be proportional to the defendant's culpability; (2) not all juveniles are sufficiently culpable to receive life without the possibility of parole as a sentence; (3) sentencing an insufficiently culpable juvenile to life without the possibility of parole is unconstitutionally disproportionate (this is why a mandatory sentencing scheme "poses too great a risk of disproportionate punishment") ${ }^{314}$; and, therefore, (4) the Eighth Amendment requires a procedure designed to protect the underlying right. ${ }^{315}$ While not explicit in the decision, Miller's reasoning only makes sense if juveniles possess a baseline constitutional right not to be sentenced to life imprisonment without the possibility of parole when insufficiently culpable. ${ }^{316}$ It is the constitutional floor - the implicit rule of Miller - that should be accorded retroactive effect.

\section{E. Miller's Retroactivity Revisited}

Miller's implicit holding does not come within any of the extant doctrinal categories. Miller still does not prohibit the punishment of primary conduct. ${ }^{317}$ Miller still does not prohibit a category of punishment for a class of defendant. ${ }^{318}$ And Miller still does not add an element to a juvenile-life-without parole sentence.

But Miller's implicit component is retroactive, for it is entirely "[] consistent with the doctrinal underpinnings of habeas review." ${ }^{19}$ Apply the hypothetical test described above: Following Miller, would a petitioner have a plausible claim that he or she is constitutionally innocent of the sentence? The answer is unequivocally yes. If the petitioner is insufficiently culpable because of his or

314. Miller, 132 S. Ct. at 2469.

315. U.S. CONST. amend. VII.

316. This conclusion is not inconsistent with Miller's statement that the Court did not "foreclose a sentencer's ability" to impose a life-without-parole sentence in a homicide case. Miller, 132 S. Ct. at 2469. Sentencers may still impose life-without-parole sentences in juvenile homicide cases even as we understand Miller; the only thing sentencers may not do is impose that sentence when a juvenile is insufficiently culpable.

What we have in mind when we say insufficiently culpable is a defendant, like Kuntrell Jackson, who was fourteen at the time of the offense in question and, so far as the record disclosed, was convicted for participating in a felony murder but did not intend to kill. See Miller, $132 \mathrm{~S}$. Ct. at 2477 (Breyer, J., concurring). We believe that, even were the state to resentence Jackson to a life-without-parole sentence using the Miller procedures (assuming Jackson could prove he did not intend to kill), his sentence would violate Miller.

317. Miller, 132 S. Ct. at 2445.

318. As explained below, there is no class of defendant as the term "class" has been used in Teague jurisprudence.

319. Bousley v. United States, 523 U.S. 614, 617 (1998). The text identified in the quotation is found at 621. Miller is not mentioned on that page, rather the Court is talking about its decision in Bailey. 
her youth, the proportionality principle of the Eighth Amendment prohibits the sentence, regardless of the procedures followed.

In this regard, Miller's implicit rule is materially indistinguishable from Atkins, the difference between them not being a matter of constitutional import. Atkins too was a proportionality principle case. ${ }^{320}$ It held that the states may not impose the death penalty on mentally retarded defendants because to do so would be constitutionally excessive. ${ }^{321}$ Atkins has been held retroactive because it barred a category of punishment (the death penalty) for a class of defendant (the mentally retarded) based on their diminished culpability. ${ }^{322}$

The only difference between Miller's implicit rule and Atkins is that Miller's implicit rule does not apply as broadly (or as cleanly) as Atkins. Like Atkins, Miller should be read to hold that the proportionality principle prohibits the imposition of a certain punishment for certain defendants by virtue of the defendants' diminished culpability. In Atkins, mentally retarded persons were a class. But in Miller, there is no readily identifiable class of individuals (not, at least, as the court has previously used the term "class"). Nevertheless, both cases are best read to remove from the states' remit the power to impose a category of punishment on certain individuals because of their culpability. ${ }^{323}$ Therefore, were Miller to be treated differently from Atkins, the only reason would be that Miller was unable to define with precision the class of defendant that could no longer receive the forbidden punishment. Such a holding would ascribe determinative doctrinal significance to the ease with which a class of defendants is defined. But the substantive-rule exception is not concerned with the difficulty of taxonimizing defendants; rather, it is concerned with whether "the Constitution itself deprives the State of the power to impose a certain penalty." 324

More importantly, "[t]he relevant frame of reference [] is not the purpose of the new rule whose benefit [defendant] seeks, but instead the purposes for which the writ of habeas corpus is made available." ${ }^{325}$ As explained by Justice Harlan in Mackey, and as elaborated in Penry, Bousley, and Schriro, the writ has historically been available to ensure that a defendant does not stand convicted of an act that the law does not make criminal or face a punishment that the law cannot impose. ${ }^{326}$ In both cases, the federal habeas statute (and likely the Constitution itself) entitles defendants to attempt to assert that defense. ${ }^{327}$

320. See generally Atkins v. Virginia, 536 U.S. 304 (2002).

321. Id. at 311-12, 321.

322. See id. at 321.

323. Like Atkins, what insufficiently culpable means should, in the first instance, be determined by the states. See infra note 358 .

324. See supra Part IV.B.2 (noting that the ease of classifying defendants according to a rule is not necessarily related to the determination of whether the rule is substantive).

325. Butler v. McKellar, 494 U.S. 407, 413 (1990) (quoting Mackey v. United States, 401 U.S. 667, 682 (1971) (Harlan, J., concurring)).

326. Schriro v. Summerlin, 542 U.S. 348, 352 (2004).

327. The scope of that defense remains to be seen. The provident course would be to mirror the Sixth Circuit's approach immediately following Atkins. In Hillv. Anderson, like in Atkins itself, 
Viewed in this light, Miller's implicit rule is quite dissimilar to the Court's procedural rule cases. Consider, for example, Lambrix v. Singletary ${ }^{328}$ and Sawyer v. Smith, ${ }^{329}$ cases in which the Court held that rules that regulated the manner of determining a defendant's sentence were procedural. ${ }^{330}$ Lambrix considered the retroactivity of Espinosa v. Florida, ${ }^{331}$ which held that a capital sentencing authority may not weigh invalid aggravating circumstances. ${ }^{332}$ The Lambrix Court summarily held that Espinosa was not retroactive. ${ }^{333}$ Sawyer considered the retroactivity of Caldwell v. Mississippi, which held that the Eighth Amendment prohibits the imposition of a death sentence by a sentencer that has been led to the false belief that the responsibility for determining the appropriateness of the defendant's sentence rests elsewhere. ${ }^{334}$ The Sawyer Court summarily concluded that Caldwell was a procedural rule. ${ }^{335}$

The rules in Espinosa and Caldwell, much like those in Woodson, Lockett, and Eddings, are "systemic rule[s] designed as an enhancement of the accuracy of . . . sentencing." 336 The defects identified in Espinosa and Caldwell could not, as a matter of constitutional law, render the defendant innocent of the sentence. Accuracy enhancing rules like those in Caldwell and Espinosa-rules that operate on "fact-finding procedures" ${ }^{337}$ —are procedural. Miller's implicit

the Sixth Circuit returned the petitioner's case to the state to allow it "the opportunity to develop its own procedures for determining whether a particular claimant is retarded and ineligible for death." Hill v. Anderson, 300 F.3d 679, 682 (2002). The principle of comity underlying habeas jurisprudence and the AEDPA counsel granting states the first attempt to delineate standards for judging culpability. Once standards have been articulated, federal courts may review a habeas petitioner's claim in light of those standards. See Allen v. Buss, 558 F.3d 657, 665 (7th Cir. 2009) (remanding to district court to hold hearing to determine whether petitioner was mentally retarded using Indiana's standard for mental retardation).

We emphasize that the result we advocate is quite narrow. Petitioners are entitled only to make the constitutional defense that life without parole cannot be imposed because of their diminished culpability. And it is generally for the states to determine where to draw that line. As with mental retardation, there are numerous dimensions on which this determination can be made: extreme youth, participation in the crime, see Miller v. Alabama, 132 S. Ct. 2445, 2475 (2012) (Breyer, J., concurring), or functional capacity, to name a few. Under our approach, a petitioner only need be resentenced if he or she can demonstrate adequately that he or she is insufficiently culpable as a constitutional matter.

328. Lambrix v. Singletary, 520 U.S. 518 (1997).

329. Sawyer v. Smith, 497 U.S. 227 (1990).

330. State supreme court decisions finding Miller procedural have relied on these cases. See, e.g., Chambers v. Minnesota, 831 N.W.2d 311, 328 (Minn. 2013).

331. Espinosa v. Florida, 505 U.S. 1079 (1992).

332. Lambrix, 520 U.S. at 518.

333. Id. at 539 .

334. Caldwell v. Mississippi, 472 U.S. 320, 328 (1985).

335. Sawyer v. Smith, 497 U.S. 227, 244 (1990).

336. Id.

337. Desist v. United States, 394 U.S. 244, 256-62 (1969) (Harlan, J., dissenting). 
holding is of a different ilk. It is not an accuracy enhancing rule. And the defect identified in Miller does render some defendants innocent of their sentences. In other words, the connection to innocence in Miller is not speculative. Were a petitioner to come within the ambit of Miller's implicit rule, it necessarily is the case that the defendant "faces a punishment that the law cannot impose upon him." "338

\section{F. Two Miscellaneous Doctrinal Points}

Two final points are in order. First, Miller was a consolidated case. ${ }^{339}$ Miller v. Alabama arrived before the Court on direct appeal and it was joined with Jackson v. Hobbs, ${ }^{340}$ a case that arrived before the Court on collateral review. Miller reversed the judgment of the Arkansas Supreme Court as to petitioner Kuntrell Jackson and remanded for further proceedings not inconsistent with the opinion. ${ }^{341}$ Some courts have relied on Jackson's procedural posture as strong support for holding Miller retroactive. ${ }^{342}$ If Miller did not apply retroactively, Jackson would have been precluded from the relief that the United States Supreme Court appeared to grant.

Jackson is a red herring. As mentioned, under Danforth, states are generally free to apply their own retroactivity rules. ${ }^{343}$ Arkansas does not apply Teague, ${ }^{344}$ and, whatever else Danforth holds, it is clear that Arkansas could apply a more generous retroactivity doctrine if it so chose - that is, Arkansas was free to hold Miller retroactive to cases on collateral review, regardless whether it was retroactive under Teague. That Miller remanded Jackson can only be read as an acknowledgement that it is generally Arkansas' sovereign prerogative to determine his entitlement to relief on state collateral review. Further diminishing

338. Schriro v. Summerlin, 542 U.S. 348, 351 (2004).

339. Miller v. Alabama, 132 S. Ct. 2445 (2012).

340. Jackson v. Hobbs, 132 S. Ct. 548 (2011) (granting cert. and joining with Miller).

341. Miller, 132 S. Ct. at 2475.

342. See, e.g., Iowa v. Ragland, 836 N.W.2d 107, 116 (Iowa 2013); Diatchenko v. Dist. Att'y for Suffolk Dist., 1 N.E.3d 270, 281-82 (Mass. 2013); Jones v. Mississippi, 122 So. 3d 698, 703 n.5 (Miss. 2013); Nebraska v. Mantich, 842 N.W.2d 716, 731 (Neb. 2014).

343. Danforth v. Minnesota, 552 U.S. 264, 282 (2008).

344. Mary C. Hutton, Retroactivity in the States: The Impact of Teague v. Lane on State Postconviction Remedies, 44 AlA. L. REV. 421, 465 (1993). On remand, the Arkansas Supreme Court agreed with the "State's concession that Jackson is entitled to the benefit of the United States Supreme Court's Opinion in his own case." Jackson v. Norris, 426 S.W.3d 906, 909-10 (Ark. 2013) (without expressly addressing Teague). The Arkansas Supreme Court cited Yates v. Aiken, 484 U.S. 211, 218 (1988), a pre-Teague case, for the proposition that a petitioner is entitled to the benefit of a United States Supreme Court decision in his or her own case. Id. at 909. But Yates held that the rule at issue was not new and observed that the state at issue did not apply a Teaguelike bar on the issues that it would entertain in collateral proceedings. See Yates, 484 U.S. at 21718. Jackson should probably be read to indicate that Arkansas grants broader relief than Teague, which under Danforth, it is entitled to do. 
the significance of Jackson is the fact that non-retroactivity under Teague is subject to waiver. ${ }^{345}$ Arkansas did not raise the issue in its brief before the United States Supreme Court, and thus the Court was under no obligation to consider whether Teague precluded relief.

The second point cuts in favor of our position. As explained by the Supreme Court of Iowa, "[i]f a substantial portion of the authority used in Miller has been applied retroactively, Miller should logically receive the same treatment." 346 Miller relied in large part on Roper, Graham, and to a lesser degree Atkins. ${ }^{347}$ Whether these cases are relevant to the retroactivity analysis depends on how Miller is understood. If Miller is read narrowly as prohibiting only mandatory life without the possibility of parole and nothing more, these cases are virtually irrelevant. Miller, lifting language directly from Teague jurisprudence, made a point of distinguishing those cases, stating "[o]ur decision does not categorically bar a penalty for a class of offenders or type of crime - as, for example, we did in Roper or Graham. Instead, it mandates only that a sentencer follow a certain process - considering an offender's youth and attendant characteristics - before imposing a particular penalty." 348 Roper and Graham, as even the Court acknowledged, categorically barred a certain penalty for a class of offenders or type of crime. ${ }^{349}$ Miller's procedural component, by contrast, mandates only a "certain process." "350

But if Miller is understood as containing a substantive component, as we have argued above, Roper, Graham, and Atkins are highly relevant. The only difference between Miller's substantive component and those three cases is that Miller did not identify a well-defined class of defendant. That distinction should not determine a defendant's ability to challenge a sentence that may in fact have been unconstitutional ab initio.

\section{Section 2254(d)(1) Should Be Read to Allow Petitioners to RELY ON NEW SUBSTANTIVE RULES}

One of the few things that is clear about the relationship between the Teague retroactivity analysis and $\S 2254(\mathrm{~d})(1)$ is that they are distinct inquiries and both must be undertaken in cases to which they apply. ${ }^{351}$ Thus, if Miller did announce

345. Caspari v. Bolen, 510 U.S. 383, 389 (1994) (“[A] federal court may . . . decline to apply Teague if the State does not argue it.").

346. Ragland, 836 N.W.2d at 116.

347. These cases generally have been given retroactive effect. See Chambers v. Minnesota, 831 N.W.2d 338 n.6 (Minn. 2013) (Anderson, J., dissenting) ("The Federal Courts of Appeals that have looked at the retroactivity of the rules articulated in Atkins, Roper, and Graham v. Florida have unanimously held that those rules are substantive in nature and thus apply to collateral appeals." (collecting cases)).

348. Miller v. Alabama, 132 S. Ct. 2455, 2471 (2012).

349. Id. at 2458-59.

350. Id. at 2471 .

351. See supra notes $104-15$ and accompanying text. 
a limited substantive rule, then a juvenile sentenced to life imprisonment without parole should be entitled to argue to a federal habeas court that his or her conviction is constitutionally impermissible - but only if $\S 2254(d)(1)$ does not operate as a bar. This section of the Article argues that it does not.

Before delving into statutory interpretation, a preliminary point is in order. Arguably, rules of the sort announced in Miller are outside the "core" of the definition of substantive rules. The first subrule of that definition-that is, the historical "core" of the definition-was that a rule is substantive if it places primary conduct outside of the power of the state to punish (take, for instance, the rule of Lawrence $v$. Texas). Only later did the Court expand the definition of substantive rules to encompass punishment, and it would require a further - though, we contend, modest and entirely logical-extension to encompass the implicit rule of Miller. It is tempting to conclude that, even assuming a case like Lawrence applies retroactively under $\S 2254(\mathrm{~d})(1)$, Miller may not, owing to its lower position in the hierarchy of subrules. ${ }^{352}$

But this conclusion would be a mistake. If a court were to hold that $\S$ 2254(d)(1) does not allow for the retroactive application of substantive rules, that means all substantive rules - the primary conduct rules of the sort at issue in Lawrence and Ex parte Siebold as well as the sentencing rules of the sort at issue in Miller and Ex parte Lange. The substantive rules stand and fall together; there is no basis either in logic or in the language of $\S 2254(\mathrm{~d})(1)$ for a holding that primary conduct-focused substantive rules apply retroactively under that section, while other types of substantive rules do not. Thus, the analysis of this section focuses, as it must, on whether $\S 2254(\mathrm{~d})(1)$ allows for the retroactivity of substantive rules in general, not simply Miller in particular.

This section proceeds as follows. We first argue that the text of $\S$ 2254(d)(1), as well as its placement in the context of the habeas statute, is ambiguous as to whether habeas petitioners subject to its strictures may retroactively rely on new substantive rules. Given this ambiguity, resort to traditional canons of statutory construction is appropriate. Here, two such canons counsel strongly in favor of our proposed reading of $\S 2254(\mathrm{~d})(1)$. The first is the rule that Congress must state an intent to effect a repeal of habeas jurisdiction with the utmost clarity. Reading $\S 2254(\mathrm{~d})(1)$ to preclude the retroactive application of substantive rules would amount to a partial abrogation of one of the most venerable functions of habeas review, allowing a petitioner to obtain federal habeas relief on the grounds that the statute under which he or she was convicted is unconstitutional or that the punishment received was beyond the court's competence to impose. Before reading the statute to effect such an abrogation, courts should require Congress to speak with much greater clarity

352. But cf. Ryan W. Scott, In Defense of the Finality of Criminal Sentences on Collateral Review, 4 WAKE FOREST J. L. \& POL'Y 179, 180 (2014) (noting that some scholars have argued that the finality interests are weaker in cases implicating only the constitutionality of a sentence than in cases where the constitutionality of the actual conviction is at stake, and hence that "collateral review of sentences, as opposed to convictions, should be subject to different and less exacting rules"). 
than it did here.

The second canon militating in favor of our proposed construction of the statute is the constitutional avoidance canon. It would raise serious constitutional questions were $\S 2254(\mathrm{~d})(1)$ to prevent a federal habeas petitioner from retroactively invoking a substantive rule established by the Supreme Court. These questions can — and should — be avoided by construing $\S 2254(d)(1)$ to allow reliance on retroactive substantive rules. ${ }^{353}$

\section{A. The Ambiguity of $\$ 2254(d)(1)$}

Our argument that $\S 2254(\mathrm{~d})(1)$ incorporates the doctrine of the retroactivity of substantive rules faces a difficulty at the outset. Congress's use of the past participle "established" in the text of the statute suggests that the correctness of the state court's decision is to be assessed against only the law in existence at the time of the relevant state court decision. ${ }^{354}$ Indeed, the Supreme Court decisions interpreting § 2254(d)(1) strongly support this reading; the Court has noted that the statute's "backward-looking language requires an examination of the statecourt decision at the time it was made." 355 Several decisions "emphasize that review under $\S 2254(\mathrm{~d})(1)$ focuses on what a state court knew and did." ${ }^{356}$ By

353. In Whorton v. Bockting, 549 U.S. 406 (2007), the Court granted certiorari on the question of whether $\$ 2254$ (d) incorporates Teague's “exceptions" to non-retroactivity. While the Court did not ultimately decide that question, the merits briefs and several of the amicus briefs filed in the case provide cogent analysis of the issue. See Petitioner's Brief on the Merits at 41-47, Whorton v. Bockting, 549 U.S. 406 (2007) (No. 05-595), 2006 WL 2066492; Respondent's Brief on the Merits, Whorton v. Bockting, 549 U.S. 406 (2007) (No. 05-595), 2006 WL 276637 at 31-47; Petitioner's Reply Brief on the Merits, Whorton v. Bockting, 549 U.S. 406 (2007) (No. 05-595), 2006 WL 3095445 at 14-20; CJLF Whorton Brief, supra note 121, at*13-23; Brief of Texas, et al. as Amicus Curiae Supporting Petitioner, Whorton v. Bockting, 549 U.S. 406 (2007) (No. 05-595), 2006 WL 2066658, at *19-27; Brief of Amici Curiae Hon. Edward N. Cahn, et al. in Support of Respondent on the Third Question Presented, Whorton v. Bockting, 549 U.S. 406 (2007) (No. 05595), 2006 WL 2725692. These briefs provided the inspiration for several of the arguments made in this section.

354. Cf. Dodd v. United States, 545 U.S. 353, 358 (2005) (stating the interpretation of a statute must "square with the ... natural reading of the text.").

355. Cullen v. Pinholster, 131 S. Ct. 1388, 1398 (2011) (holding that federal court engaging in habeas review of a state-court decision may consider only the record before the state court).

356. Id. at 1399; see also Greene v. Fisher, 132 S. Ct. 38, 44 (2011) (holding that "clearly established Federal law, as determined by the Supreme Court of the United States," refers to the Court's decisions as of the time of the last state-court adjudication on the merits, rather than the time at which the defendant's conviction becomes final); Lockyer v. Andrade, 538 U.S. 63, 71 (2003) (quoting Williams v. Taylor, 529 U.S. 362, 412 (2000)) (“Section 2254(d)(1)'s 'clearly established' phrase 'refers to the holdings, as opposed to the dicta, of this Court's decisions as of the time of the relevant state court decision.'”).

One could plausibly argue that the Court's focus on the temporal element of $\S 2254(\mathrm{~d})(1)$ is misplaced. The legislative history of the AEDPA suggests that $§ 2254(d)(1)$ was intended simply 
definition, a "new rule"- that is, a rule announced after the petitioner's conviction became final that "br[oke] new ground" and was "not dictated by precedent" 357 - was not "clearly established" at the time of that decision.

Ultimately, however, this argument is unconvincing. The Court's retroactivity doctrine, which is derived from 28 U.S.C. $\$ 2243$ (directing federal courts to dispose of habeas petitions "as law and justice require"), is about remedies, or, as the Court has termed it, "redressability": "[w]hat [the Court is] actually determining when [it] assess[es] the 'retroactivity' of a new rule is not the temporal scope of a newly announced right, but whether a violation of the right that occurred prior to the announcement of the new rule will entitle a criminal defendant to the relief sought." 358 That is, the Teague analysis does not "define the scope of the "new' constitutional rights themselves"; it merely sets forth "what constitutional violations may be remedied on federal habeas." ${ }^{359}$ It follows that the temporal scope of a given constitutional right and whether a defendant who has suffered a violation of that right is entitled to relief are distinct issues.

Section 2254(d)(1), as interpreted by the Supreme Court, addresses itself to the temporal question. To see why, consider again the three-step Teague inquiry and its relationship to $\S 2254(\mathrm{~d})(1)$, as explicated in Williams. The first step of the Teague analysis - determining whether a rule is old or new in relation to the time at which the petitioner's conviction became final - is exclusively temporal in nature. ${ }^{360}$ The second two steps - determining whether one of the Teague exceptions applies and hence whether a new rule will apply retroactively-are remedial. In Williams, Justice O'Connor explained that the question of whether

to ensure that federal courts defer to their state counterparts' reasonable interpretations of United States Supreme Court case law. See Bryant, supra note 15, at 25-29 (arguing that the text, structure, and legislative history of the AEDPA suggest that it required "deference to state court determinations of factual questions or mixed questions of law and fact"); Kent S. Scheidigger, Habeas Corpus, Relitigation, and the Legislative Power, 98 ColuM. L. REV. 888, 945 (1998) (noting that every member of Congress who advocated for or against $\S 2254(d)(1)$ called it a “"deference' standard”); see also Williams v. Taylor, 529 U.S. 362, 412 (2000) (holding that, under $\S 2254(d)(1)$, federal courts may not overturn "incorrect or erroneous" applications of federal law unless they are "unreasonable"). That goal could still be achieved even without pegging the temporal focus of the statute to the time of the state court's decision. If a state court renders a decision at time $t$ and the Supreme Court renders a decision on the same issue at time $t+1$, a federal court could simply determine whether the state court's decision is "reasonable" in light of the Supreme Court's later decision, which would, at the time of the habeas adjudication, be "clearly established federal law." That is, the temporal language in $\S 2254(d)(1)$ could be meant only as a limitation on federal habeas courts' ability to grant relief when the Supreme Court has not yet clearly articulated a right.

357. Teague v. Lane, 489 U.S. 288, 301 (1989).

358. Danforth v. Minnesota, 552 U.S. 264, $271 \&$ n.5 (2008).

359. Id. at 275. See generally Fallon \& Meltzer, supra note 26, at 1731 (arguing that "new law" doctrines are best analyzed in the framework of the law of constitutional remedies).

360. Williams v. Taylor, 529 U.S. 362, 367-48 (2000). 
a rule constitutes "clearly established federal law" is parallel to the determination under Teague of whether a rule is new or old. ${ }^{361}$ Thus, $\S 2254(\mathrm{~d})(1)$ tells us the temporal scope of Supreme Court decisions to which federal habeas courts should normally attend when presented with collateral attacks on criminal convictions, but it is silent - and thus ambiguous ${ }^{362}$ - regarding the remedial question of when, if ever, a petitioner whose "new" constitutional rights have been violated may obtain relief on habeas. That is, under $\S 2254(\mathrm{~d})(1)$, in the mine-run of cases, courts should apply only clearly established law, as articulated by the United States Supreme Court. But the statute does not answer the question to which Teague's substantive rule exception is addressed: the appropriate remedy in the extraordinary case in which a petitioner's substantive rights have been violated. Put somewhat differently, § 2254(d)(1) leaves unclear whether Teague's interpretation of $\S 2243$ to allow retroactive application of new rules in certain circumstances is still good law in cases where $\S 2254(\mathrm{~d})(1)$ is applicable. Unless $\S 2254(\mathrm{~d})(1)$ amounts to a sub silentio repeal of part of $\S$ $2243,{ }^{363}$ we are left with two provisions in the same statute that are in tension with each other. Section 2243 condones relief for habeas petitioners wishing to rely on certain categories of new rules, whereas $\S 2254$ (d)(1) might be read to prohibit such relief. This arguable conflict in the statutory scheme is another, related source of ambiguity. ${ }^{364}$

Other considerations lend support to our assertion that Congress did not intend $\S 2254(\mathrm{~d})(1)$ to speak to the retroactivity/redressability question. First, the following statement of the sponsor of the AEDPA, Senator Hatch, suggests that the statute was intended to incorporate, in wholesale fashion, the Court's retroactivity jurisprudence:

$[\mathrm{U}]$ nder our habeas corpus reform provisions ... people's rights will be protected. There will be a full right of appeal all the way up the State courts .... There will be a full right of appeal all the way up the Federal courts .... But that is all [prisoners] are going to have, unless they can show newly discovered evidence of innocence or unless the Supreme Court applies retroactively future cases to these problems. ${ }^{365}$

361. Id. at 412 (2000) ("[W]hatever would qualify as an old rule under our Teague jurisprudence will constitute "clearly established Federal law, as determined by the Supreme Court of the United States' under $\S 2254(d)(1) . ”)$.

362. $C f$. INS v. Aguirre-Aguirre, 526 U.S. 415, 424 (1999) (citing Chevron U.S.A. Inc. v. Nat'1 Res. Def. Council, Inc., 467 U.S. 837, 843 (1984)) (equating the concepts of statutory silence and statutory ambiguity).

363. Cf. Morton v. Mancari, 417 U.S. 535, 550 (1974) ("In the absence of some affirmative showing of an intention to repeal, the only permissible justification for a repeal by implication is when the earlier and later statutes are irreconcilable.").

364. See City of Arlington v. FCC, 133 S. Ct. 1863, 1876 (2013) (noting that "the structure of the statutory scheme" is relevant in determining whether a statute is ambiguous).

365. 141 CONG. REC. S7479-03 (daily ed. May 25, 1995) (statement of Sen. Hatch) (emphasis added). 
Senator Hatch's words strongly suggest that the phrase "clearly established" was meant to address temporality as opposed to redressability.

Second, Congress considered and rejected an amendment (the "Kyl Amendment") that would have stripped the federal courts of jurisdiction to review state court determinations entirely unless the remedies of the state court were inadequate or ineffective to test the legality of a person's detention. ${ }^{366} \mathrm{In}$ some respects, reading $\S 2254(\mathrm{~d})(1)$ to eliminate Teague's exception for substantive rules would go even further than the Kyl Amendment; it would preclude relief in some cases even if the state court's remedies did not adequately test the legality of the prisoner's conviction. ${ }^{367}$ That Congress rejected this amendment strongly suggests that it did not intend $\S 2254(d)(1)$ to speak to the redressability question.

Moreover, as is explained below, reading $\S 2254(d)(1)$ to preclude retroactive application of substantive rules would run afoul of two "clear statement" canons of statutory construction. Courts presume that Congress is aware of clear statement canons and will draft statutes accordingly. ${ }^{368}$ Thus, that Congress did not clearly evince an intent to preclude the retroactive application of substantive rules to habeas petitioners subject to $\S 2254$ (d)(1) suggests that it intended not to do so.

Indeed, at the time Congress enacted the AEDPA, the Supreme Court had not yet explained that the Teague rule was derived from the federal habeas statute; that explanation came over ten years later, in Danforth. ${ }^{369}$ It is possible-even

366. See generally 141 CONG. REC. S7829 (daily ed. June 7, 1995); see also Carrie M. Bowden, The Need for Comity: A Proposal for Federal Court Review of Suppression Issues in the Dual Sovereignty Context After the Antiterrorism and Effective Death Penalty Act of 1996, 60 WASH. \& LEE L. REV. 185, 223-24 (2003).

367. Yet another reason to think it unlikely that Congress intended to eliminate retroactivity for petitioners subject to $\S 2254(\mathrm{~d})(1)$ is found by considering the situation of a petitioner who wishes to claim the benefit of a new substantive rule that was issued after the controlling appellate state court decision but before his conviction became final. It is a "basic norm of constitutional adjudication" that new rules must be applied to criminal cases pending on direct review. Griffith v. Kentucky, 479 U.S. 314, 322 (1987). However, reading § 2254(d)(1) to preclude the retroactive application of substantive rules on collateral review would mean that a federal court could not give this petitioner relief under Griffith. This anomaly arises because Teague defines the temporal cutoff between old and new rules as the time the petitioner's conviction becomes final, whereas, under $\S$ 2254(d)(1), the "clearly established law" is assessed as of the time of the last state court decision on the merits. See Greene v. Fisher, 132 S. Ct. 38, 44 (2011)). Such a result must be avoided; not only would it be absurd, $c f$. United States v. Wilson, 503 U.S. 329, 334 (1992), but it would also likely give rise to serious constitutional questions. See Griffith, 479 U.S. at 322 ("[F]ailure to apply a newly declared constitutional rule to criminal cases pending on direct review violates basic norms of constitutional adjudication.").

368. Lockhart v. United States, 546 U.S. 142, 148-49 (2005).

369. Compare Danforth v. Minnesota, 552 U.S. 264, 278 (2008) (“Teague"s general rule of nonretroactivity was an exercise of th[e] Court's power to interpret the federal habeas statute."), 
likely - that Congress viewed Teague as announcing a background constitutional principle that it was not free to alter, whether explicitly or by implication. ${ }^{370}$ Congress may have felt it unnecessary to include an explicit provision in the statute stating that substantive rules apply retroactively for purposes of the $\S$ 2254(d)(1) analysis, since that doctrine was simply part of the background against which Congress legislated. ${ }^{371}$ Likewise, Congress may not have felt itself free constitutionally to legislate away the retroactivity of substantive rules of criminal law.

Even if one does not accept our argument that $\S 2254(d)(1)$ does not exclusively concern redressability, it would still be the case that the statute is ambiguous as to whether it incorporates the principle that substantive rules are retroactive on collateral review. Recall that the Court has stated since Teague that Teague's "exception" to nonretroactivity for new substantive rules is not really an "exception" at all. ${ }^{372}$ Instead, substantive rules are simply "not subject to the bar" - that is, they apply to all convictions, period, no matter when the conviction became final. ${ }^{373}$ If substantive rules are not subject to the Teague bar on retroactive application of new rules, they logically would not be subject to $\S$ 2254(d)(1)'s bar on consideration of law that was not clearly established at the time of the state court adjudication, particularly since the leading Supreme Court opinion on what constitutes "clearly established" federal law ties that phrase to Teague's concept of new and old rules. Thus, even if $\S 2254(\mathrm{~d})(1)$ does address the remedial question, that the statute does not include a substantive rule "exception" to its bar on relitigation of claims adjudicated in state court does not necessarily mean that it was intended to jettison the doctrine that substantive rules always apply retroactively. ${ }^{374}$

To sum up the analysis to this point: $\S 2254(d)(1)$ 's "backward-looking" language suggests that a federal court considering the correctness of a state court adjudication should look at the state of the law and evidence before the court at the time it made its decision. However, the question under consideration - the

with id. at 308 \& n.4 (Roberts, C.J., dissenting) (noting that the Court had never before explicitly stated that Teague was a statutory decision and that Teague itself cited the federal habeas statute only "once in passing").

370. See id. at 308-09 \& n.4 (Roberts, C.J., dissenting) (expressing doubt as to the majority's conclusion that Teague was an interpretation of the federal habeas statute and suggesting that the decision has constitutional roots). Even after Danforth, it is still arguable that the Teague "exceptions" are derived from the Constitution, even if Teague's general bar on retroactivity is not. See Rewriting the Great Writ, supra note 117, at 1884 (arguing that the Teague exceptions are rooted in the Due Process Clause and the Suspension Clause).

371. Cf. Marx v. Gen. Revenue Corp., 133 S. Ct. 1166, 1175 (2013) (noting that background presumptions regarding the subject of the statute in question "are highly relevant contextual features" that may shed light on the meaning of the statute).

372. Schriro v. Summerlin, 542 U.S. 348, 352 n.4 (2004).

373. Id.

374. Whether this reasoning holds true for Teague's exception for watershed procedural rules is much less clear; but that question is beyond the scope of this Article. 
retroactivity question - is not about the temporal dimensions of constitutional rights, nor is it about the correctness vel non of the state court's decision under the law as it existed at the time of the decision. It is about whether a petitioner whose constitutional rights concededly have been violated is entitled to redress for that violation. The plain language of $\S 2254(\mathrm{~d})$ does not resolve that question. Instead, in order to interpret the statute to preclude reliance on retroactive rules, one must infer such a prohibition from Congress's silence regarding the remedial question. Further analysis is required in order to determine whether such an inference is warranted.

One might look to the statutory context — that is, the surrounding provisions of the AEDPA - for further clues of Congressional intent with respect to whether $\S 2254(\mathrm{~d})(1)$ is intended to allow for retroactivity. ${ }^{375}$ In four other places in the AEDPA, Congress explicitly allowed petitioners to rely on new rules that are deemed retroactive on collateral review. ${ }^{376}$ First, $\S 2244(\mathrm{~b})(2)(\mathrm{A})$ permits second or successive habeas petitions that include a claim that "relies on a new rule of constitutional law, made retroactive to cases on collateral review by the United States Supreme Court, that was previously unavailable." ${ }^{377}$ Second, § 2244(d)(1)(C) provides that the one-year statute of limitations period applicable to habeas applications from state prisoners may run anew from the date that the United States Supreme Court newly recognizes a right and makes it retroactively applicable to cases on collateral review. ${ }^{378}$ Third, $\S 2254(\mathrm{e})(2)(\mathrm{A})(\mathrm{i})$ provides that, if the petitioner failed to develop the factual basis of his claim in state court, a federal court may hold an evidentiary hearing if the petitioner's claim relies on "a new rule of constitutional law, made retroactive to cases on collateral review by the United States Supreme Court, that was previously unavailable." ${ }^{379}$ Finally, $\S 2264(\mathrm{a})(2)$ instructs that a federal court may consider a capital prisoner's claim that was not raised and decided on the merits in state court if the prisoner's failure to raise the claim properly was "the result of the Supreme Court's recognition of a new federal right that is made retroactively applicable." "380

But it is unclear which way these observations cut. On one hand, "it is a general principle of statutory construction that when one statutory section includes particular language that is omitted in another section of the same Act, it is presumed that Congress acted intentionally and purposely." ${ }^{\prime 31}$ That Congress chose to explicitly provide for retroactivity in some parts of the AEDPA, but not in $\S 2254(\mathrm{~d})(1)$, might suggest that it did not intend to

375. See Roberts v. Sea-Land Servs., Inc., 132 S. Ct. 1350, 1357 (2012) (“"It is a fundamental canon of statutory construction that the words of a statute must be read in their context and with a view to their place in the overall statutory scheme."” (quoting Davis v. Mich. Dept. of Treas., 489 U.S. 803, 809 (1989)).

376. 28 U.S.C. $\S \S 2244(b)(2)(a), 2244(d)(1)(C), 2254(e)(2)(A)(i), 2264(a)(2)(2014)$.

377. Id. $\S 2244(\mathrm{~b})(2)(\mathrm{a})$.

378. Id. § 2244(d)(1)(C).

379. Id. $\$ 2254(\mathrm{e})(2)(\mathrm{A})(\mathrm{i})$.

380. Id. $\S 2264(\mathrm{a})(2)$.

381. Barnhart v. Sigmon Coal Co., 534 U.S. 438, 439-40 (2002). 
incorporate Teague principles into the latter provision. ${ }^{382}$

On the other hand, one might argue that it is unlikely that Congress would have intended to allow petitioners to rely on Teague's exceptions to nonretroactivity in some respects, yet then, in $\S 2254(\mathrm{~d})(1)$, preclude them from ultimately obtaining relief. For instance, suppose that a state prisoner under capital sentence wishes to file a federal habeas petition based on "the Supreme Court's recognition of a new Federal right that is made retroactively applicable." ${ }^{383}$ Section 2264 would specifically allow the petitioner to raise that claim for the first time in federal district court, without first going to state court to obtain an adjudication on the merits. ${ }^{384}$ But such a petitioner would also be subject to $\S 2254(d)(1)$ - meaning that, if that section does not allow for the retroactive application of new substantive rules, the petitioner's claim for relief would have passed the hurdle of $\S 2264$ only to be immediately frustrated by $\S$ 2254(d)(1). ${ }^{385}$ This result would render $\S 2264(a)(2)$ 's allowance for retroactivity essentially meaningless, in violation of the canon of construction that disfavors "an interpretation of a congressional enactment which renders superfluous another portion of that same law." 386

In short, that Congress provided for retroactive application of new rules elsewhere in the AEDPA does not militate in favor of either construction of the statute. Since neither the text nor the structure of the AEDPA yields a clear answer as to whether Congress intended it to allow for the retroactive application of substantive rules, resort to other tools of statutory interpretation is necessary. In the following two sections, we argue that two longstanding canons of construction - the presumption against repeals of habeas jurisdiction and the constitutional doubt canon - compel our proposed reading of the statute.

\section{B. Section 2254(d)(1) Lacks a Clear Indication That It was Intended to Repeal the Federal Courts' Habeas Jurisdiction}

As discussed at length above, the writ of habeas corpus has historically been available as a means through which state prisoners can challenge their confinement pursuant to judicial process on the grounds that the statute under which they were convicted is unconstitutional or the punishment they received could not be imposed. Reading $\S 2254(d)(1)$ to preclude retroactive application of substantive rules would thus amount to a repeal by implication of part of the federal courts' habeas jurisdiction - and a particularly venerable portion, at

382. See Green v. French, 143 F.3d 865, 873 (4th Cir. 1998) (“declin[ing] to interpret ... section $2254(\mathrm{~d})$ as simply codifying the Teague doctrine, because that doctrine . . . nowhere employs the 'new rule' language of Teague, even though other provisions of the AEDPA do so unmistakably").

383. 28 U.S.C. $§ 2264$ (2012).

384. See id.

385. See id. ("Following review subject to subsections (a), (d), and (e) of section 2254, the court shall rule on the claims properly before it.").

386. United States v. Jicarilla Apache Nation, 131 S. Ct. 2313, 2330 (2011). 
that ${ }^{387}$ Indeed, the substantive law "exception" to the general bar to retroactive application of new rules on collateral review is a direct descendant of the core purpose of habeas corpus: allowing petitioners to challenge a judicially authorized detention on the grounds that the detaining court lacked jurisdiction over the petitioner's case. ${ }^{388}$ The Court has recognized since at least the mid19 th century that such "jurisdictional challenges" encompass arguments that the petitioner was convicted under an unconstitutional statute or that he had been subjected to a punishment that the law could not impose. ${ }^{389}$ When Justice Harlan, the grandfather of modern retroactivity doctrine, recognized an "exception" to the retroactivity bar for substantive rules, it was with the purpose of maintaining this core function of the Great Writ. ${ }^{390}$

The Supreme Court has long held that "[r]epeals by implication are not favored," and "are seldom admitted except on the ground of repugnancy." "391 This is particularly so when it comes to repeals of habeas jurisdiction, which may not be inferred absent "an unmistakably clear statement" that such was Congress's intent. ${ }^{392}$ "Implications from statutory text or legislative history are not sufficient to repeal habeas jurisdiction; instead, Congress must articulate specific and unambiguous statutory directives to effect a repeal." ${ }^{393}$

The presumption against repeal of habeas jurisdiction is exceedingly strong, as is evidenced by the two most recent Supreme Court decisions implicating this canon of construction. In St. Cyr, the habeas petitioner, an alien, had pleaded guilty to a criminal charge that rendered him subject to deportation. ${ }^{394}$ The Attorney General claimed that the AEDPA and the Illegal Immigrant Reform and Immigrant Responsibility Act of 1996 ("IIRIRA"), ${ }^{395}$ withdrew his authority to grant St. Cyr a waiver of deportation. ${ }^{396}$ The INS argued before the Court that the federal courts did not have jurisdiction to entertain St. Cyr's habeas petition. ${ }^{397}$ The majority, in an opinion by Justice Stevens, rejected that

387. Mackey v. United States, 401 U.S. 667, 692 (1971) (Harlan, J., concurring in part and dissenting in part); see also Ex parte Siebold, 100 U.S. 371, 376 (1879) (determining that federal court may entertain a habeas application from a state prisoner who argues that the statute under which he was convicted was unconstitutional); FALLON ET AL., supra note 9, at 1264.

388. See supra notes 205-15 and accompanying text.

389. See, e.g., Siebold, 110 U.S. at 371; Ex parte Lange, 85 U.S. 163 (1873). See generally Mackey, 401 U.S. at 692 (Harlan, J., concurring in part and dissenting in part).

390. Mackey, 401 U.S. at 675-702 (Harlan, J., concurring in part and dissenting in part).

391. Ex parte Yerger, 75 U.S. 85, 105 (1868).

392. Hamdan v. Rumsfeld, 548 U.S. 557, 575 (2006); see also I.N.S. v. St. Cyr., 533 U.S. 289 , 298 (2001) (noting the "longstanding rule requiring a clear statement of congressional intent to repeal habeas jurisdiction").

393. St. Cyr, 533 U.S. at 299.

394. Id. at 293-94.

395. Illegal Immigrant Reform and Immigration Responsibility Act of 1996, Pub. L. No. 104208, 110 Stat. 3009 (1996).

396. St. Cyr, 533 U.S. at 293-94.

397. Id. at 298-99. 
contention. ${ }^{398}$

Justice Stevens began his opinion by stating that, in order to prevail, the INS would have to overcome several obstacles: the "longstanding rule requiring a clear statement of congressional intent to repeal habeas jurisdiction"; ${ }^{399}$ the doctrine that "when a particular interpretation of a statute invokes the outer limits of Congress's power, we expect a clear indication that Congress intended that result", 400 and the obligation of courts to, if "fairly possible," construe statutes in such a way as to avoid "serious constitutional problems." 401 The Court then concluded that the text of the AEDPA did not evince a sufficiently clear intent to repeal federal courts' jurisdiction to hear habeas petitions by detained aliens-notwithstanding the fact that the statute contained a section titled "ELIMINATION OF CUSTODY REVIEW BY HABEAS CORPUS." 402 Neither did the text of the IIRIRA, even though it explicitly stated that " no court shall have jurisdiction to review any final order of removal against an alien who is removable by reason of having committed' certain enumerated criminal offenses." 403 The Court explained that "judicial review" historically has a different meaning than "habeas corpus." " 04 Because the provisions relied on by the INS mentioned "judicial review" but did not contain the word "habeas," the provisions did not "speak[] with sufficient clarity to bar jurisdiction pursuant to the general habeas statute." 405 In dissent, Justice Scalia excoriated the majority for "fabricat[ing] a superclear statement, 'magic words' requirement for the congressional expression of . . an intent ..." to preclude habeas review. ${ }^{406}$

In Hamdan, the Court considered a statute with arguably even more explicit jurisdiction-stripping language: the Detainee Treatment Act ("DTA"), ${ }^{407} \S$ 1005(e)(1) of which provided that "no court, justice, or judge shall have

398. Id. at 304-05.

399. Id. at 298-99 (citing Ex parte Yerger, 75 U.S. 85, 105 (1868); Felker v. Turpin, 518 U.S. 651, 660-61 (1996).

400. Id. at 299 (citing Edward J. DeBartolo Corp. v. Florida Gulf Coast Bldg. \& Constr. Trades Council, 485 U.S. 568, 575 (1988)).

401. Id. at 308-09 (citing Ashwander v. TVA, 297 U.S. 288, 341, 345-348 (1936) (Brandeis, J., concurring); United States ex rel. Attorney Gen. v. Delaware \& Hudson Co., 213 U.S. 366, 408 (1909)).

402. Id.; see also Melissa Patterson, Surely You Didn't Mean "No” Jurisdiction: Why The Supreme Court's Selective Hearing in Hamdan Is Good For Democracy, 1 HARV. L. \& POL'Y REV. 279, 281 (2007). Justice Stevens reasoned that the text of the provision merely amended the judicial review provisions of the 1952 Immigration and Nationality Act and made no mention of the general habeas statute, 28 U.S.C. $\S 2241$. St. Cyr, 533 U.S. at 309.

403. St. Cyr, 533 U.S. at 311 (citing 8 U.S.C. $\S 1252(\mathrm{a})(2)(C)(2012)$ ).

404. Id.

405. Id. at 312-13.

406. Id. at 327 (Scalia, J., dissenting); cf. FALLON ET AL., supra note 9, at 317 ("Many commentators sympathetic to the [St. Cyr.] majority's approach would not dispute Justice Scalia's claim that the Court's statutory interpretation bordered on a demand for 'magic words."').

407. Detainee Treatment Act, Pub. L. No. 109-148, 119 Stat. 2739 (2005). 
jurisdiction to hear or consider . . . an application for a writ of habeas corpus filed by or on behalf of an alien detained ... a at Guantanamo Bay." ${ }^{408}$ The Court held that this provision did not repeal the Court's jurisdiction over cases (like Hamdan's) pending on the effective date of the DTA. ${ }^{409}$ The majority, again per Justice Stevens, reasoned that, because another provision of the DTA instructed that $\S \S 1005(\mathrm{e})(2)$ and $(\mathrm{e})(3)$ should be applied to pending cases, a negative inference arose that $\S 1005(\mathrm{e})(1)$ was not intended to apply to pending cases. ${ }^{410}$ The Court acknowledged that its analysis was arguably counter to the usual rule that "Congress's failure to expressly reserve federal courts' jurisdiction over pending cases erects a presumption against jurisdiction." 411 Justice Scalia, again in dissent, criticized the majority for "ma[king] a mess of th[e] statute" and argued that it "unambiguously terminate[d] the jurisdiction of all courts to "hear or consider' pending habeas applications." 412

St. Cyr and Hamdan, taken together, teach that the presumption against repeal of habeas jurisdiction is a particularly powerful "clear statement" canon of statutory interpretation. ${ }^{413}$ Such a repeal will not be found unless there is a truly "unambiguous statutory directive" that the repeal was intended. ${ }^{414}$ It is

408. Hamdan v. Rumsfeld, 548 U.S. 557, 573 (2006) (quoting DTA § 1005(e)(1)); see also Patterson, supra note 402, at 279 ("Congress at last appeared to make real that much-debated but largely hypothetical creature of Federal Courts class discussions, the full-fledged, unambiguous jurisdiction strip, and declared that 'no court, justice, or judge shall have jurisdiction to hear or consider' habeas or any other action filed by Guantanamo Bay detainees.").

409. Hamdan, 548 U.S. at 575-76.

410. Id. at 576 .

411. Id.; see also id. at 656 (Scalia, J., dissenting) ("An ancient and unbroken line of authority attests that statutes ousting jurisdiction unambiguously apply to cases pending at their effective date.").

412. Id. at 669 (Scalia, J., dissenting).

413. See, e.g., Brian G. Slocum, Overlooked Temporal Issues in Statutory Interpretation, 81 TEMP. L. REV. 635, 687 n.157 (2008) (noting that "[t]he rule requiring a clear statement of congressional intent to repeal habeas jurisdiction is [a] super-clear statement rule" that "require[s] extremely explicit statutory language in order to overcome [its] presumptions"). One might even argue that, based on the methodology employed in St. Cyr, the canon can sometimes trump the plain text of the statute. Justice Stevens began his analysis with a discussion of the clear statement rule, and reproduced the actual text of the statute much later. I.N.S. v. St. Cyr, 533 U.S. 289, 299, 308 (2001). Justice Scalia was highly critical of this feature of the majority opinion. See id. at 327 (Scalia, J., dissenting) (arguing that it "would have been readily apparent to the reader" that the IIRIRA repealed habeas jurisdiction to certain deportation challenges "had the Court at the outset of its opinion set forth the relevant provisions" of the statutes in question). Even if the clear statement rule could not overcome plain text, however, it certainly will strongly inform the interpretation of ambiguous statutes like 28 U.S.C. $§ 2254(d)(1)$.

414. St. Cyr, 533 U.S. at 299. Indeed, the Supreme Court has quoted Justice Scalia's criticism of St. Cyr as establishing "“a superclear statement, magic words requirement for the congressional expression' of an intent to preclude habeas review" in support of the proposition that an exceedingly clear statement is required to repeal habeas jurisdiction. Demore v. Kim, 538 U.S. 510 , 
notable that St. Cyr concerned jurisdiction over a habeas petition filed by an alien who had been detained pending removal. Such proceedings are not "core" habeas proceedings. ${ }^{415}$ Similarly, in Hamdan, it was debatable whether the petitioner, a Guantanamo detainee, was entitled to the protection of the Suspension Clause at all. ${ }^{416}$ If the presumption against repeal of habeas jurisdiction is strong when it comes to cases like these, which implicate the periphery of the scope of the Great Writ, it should arguably be even stronger when it comes to cases closer to the writ's historical core. As explained above, very early on in the course of the Court's habeas jurisprudence, jurisdictional challenges to detention with judicial process - which included arguments that the petitioner had been convicted under an unconstitutional statute-were held to be sufficiently close to that core to be cognizable on federal habeas. ${ }^{417}$ Substantive rules are directly descended from such challenges, and thus are close to the historical core as well.

An examination of the language of $\S 2254(d)(1)$ reveals that the requisite "unambiguous directive" to effect a repeal of habeas jurisdiction is absent from the provision. The statute does not explicitly state that it precludes the retroactive application of substantive rules. Indeed, to argue that $\S 2254(\mathrm{~d})(1)$ does not permit the retroactive application of substantive rules, one would have to do just what St. Cyr forbids: begin with the premises that (1) the statute uses "backward-looking" language and (2) the statute does not explicitly allow for the retroactivity of substantive rules, and then infer the conclusion that the statute does not contemplate retroactivity.

Moreover, our observation that $\S 2254(\mathrm{~d})(1)$ explicitly concerns temporality, but not redressability, parallels the St. Cyr Court's observation that the IIRIRA explicitly addressed "judicial review" but not "habeas corpus." 418 St. Cyr reasoned that the IIRIRA's failure to unequivocally state that it applied to habeas review meant that it did not so apply. ${ }^{419}$ Similarly, here, the AEDPA's failure to address explicitly the remedial issues surrounding the law of retroactivity strongly suggests that the statute does not preclude reliance on previouslyexisting retroactivity principles.

In short, we contend that the presumption against implied repeal of habeas jurisdiction weighs strongly in favor of our proposed reading of $\S 2254(\mathrm{~d})(1)$.

517 (2003) (internal quotation marks omitted); see also FALLON ET AL., supra note 9, at 317 n.2.

415. See, e.g., St. Cyr, 533 U.S. at 304 (noting the INS's "not insubstantial" historical arguments that St. Cyr's petition fell outside the traditional scope of the writ at common law); Farez-Espinoza v. Chertoff, 600 F. Supp. 2d 488, 495 (S.D.N.Y. 2009).

416. See Hamdan, 548 U.S. at 670 (Scalia, J., dissenting) (arguing that the Guantanamo detainees had no rights under the Suspension Clause because the military base was outside the territorial jurisdiction of the United States).

417. Of course, the true "core" function of the writ is to allow those subject to unlawful executive detention without judicial process to obtain redress. See supra note 205 and accompanying text.

418. St. Cyr, 533 U.S. at 290.

419. Id. 


\section{Reading \& 2254(d)(1) to Preclude the Retroactive Application of Substantive Rules Would Raise Serious Constitutional Doubts}

It is a bedrock principle of interpretation that "[a] statute must be construed, if fairly possible, so as to avoid not only the conclusion that it is unconstitutional but also grave doubts upon that score." ${ }^{\$ 20}$ Construing $§ 2254(d)(1)$ in a manner that could prevent petitioners convicted under an unconstitutional statute from challenging the validity of their confinement would raise serious concerns under both the Due Process Clause and the Suspension Clause. ${ }^{421}$

First, with regard to the Due Process Clause: the writ of habeas corpus has traditionally been available for petitioners who wish to attack their convictions on the ground that the conduct for which the petitioner was imprisoned is "beyond the power of the criminal law-making authority to proscribe" ${ }^{22}$ or that he or she was subjected to a punishment that the law could not impose. Such situations, Justice Harlan explained, "represent[] the clearest instance[s] where finality interests should yield," because "[t]here is little societal interest in permitting the criminal process to rest at a point where it ought properly never to repose. ${ }^{, 423}$ Were Congress to curtail this historic function of habeas review, it would arguably violate the substantive due process rights of petitioners wishing

420. Almendarez-Torres v. United States, 523 U.S. 224, 237-38 (1998) (quoting United States v. Jin Fuey Moy, 241 U.S. 394, 401 (1916)).

421. The few courts and commentators to address the statutory construction issue under consideration have focused primarily on the constitutional doubts that would be raised if habeas petitioners subject to $\S 2254(\mathrm{~d})(1)$ could not rely on the "Teague exceptions." See Bockting v. Bayer, 399 F.3d 1010, 1021 (9th. Cir. 2005) (“[E]ven if Congress' intent is unclear, the constitutional doubt canon of construction mandates that we read [ $\$ 2254(\mathrm{~d})(1)]$ to incorporate the Teague exceptions to avoid the serious constitutional problem raised by depriving individuals of bedrock principles of Due Process."), rev'd on other grounds sub nom Whorton v. Bockting, 549 U.S. 406 (2007); Mungo v. Duncan, 393 F.3d 327, 334-35 (2d Cir. 2004) (suggesting that $\S$ 2254(d)(1) "out of prudence should be read[] to adopt the Teague exceptions" because otherwise, "if a state criminal conviction were obtained in a manner later determined by the Supreme Court to be not only unconstitutional but also incompatible with fundamental fairness and fraught with an 'impermissibly large risk that the innocent will be convicted,' . . the federal courts would nonetheless be compelled to reject the petition and accept the potentially inaccurate and fundamentally unfair conviction, so long as the state court had affirmed on the merits" (internal quotation marks and citation omitted)); Khandelwal, supra note 117, at $440 \mathrm{n} .45$ (arguing that "the statute should be interpreted to codify the Teague exceptions because they have 'roots in due process concerns,' and so eliminating them might raise constitutional objections" (citation omitted)); Rewriting the Great Writ, supra note 117, at 1884-85 (arguing that $\S 2254(\mathrm{~d})$ (1) should be read to incorporate both Teague exceptions because a contrary interpretation would raise concerns under the Due Process Clause and Suspension Clause). As said, our focus is not on the Teague exceptions as a unit but rather on the principle that substantive rules apply retroactively.

422. Mackey v. United States, 401 U.S. 667, 692-93 (1971) (Harlan, J., concurring in part and dissenting in part).

423. Id. at 693 . 
to rely on new substantive rules. ${ }^{424}$ The Seventh Circuit has stated it bluntly: "If it would be unconstitutional to punish a person for an act that cannot be subject to criminal penalties it is no less unconstitutional to keep a person in prison for committing the same act." 425 "This proposition," one commentator has noted, "seems undeniable; it is hard to imagine, [for example], that Virginia might keep in jail interracial couples who had cohabited within the state before Loving $v$. Virginia." ${ }^{\prime 26}$

Turning to the Suspension Clause, the United States Supreme Court has noted that the protection of the Clause, "at the absolute minimum, ... protects the writ 'as it existed in 1789.'",427 Thus, in order to determine whether a given restriction on the scope of the Great Writ constitutes an unconstitutional "suspension," a court would have to "answer the difficult question of what the Suspension Clause protects." ${ }^{428}$ This "is in and of itself a reason to avoid answering constitutional questions that would be raised by concluding that [habeas] review [is] barred entirely" for a class of petitioner who could traditionally have challenged their

424. See id. at 692 ("New 'substantive due process' rules, that is, those that place, as a matter of constitutional interpretation, certain kinds of primary, private individual conduct beyond the power of the criminal law-making authority to proscribe, must . . . be placed on a different footing."); Khandelwal, supra note 117, at 440 n.45; Rewriting the Great Writ, supra note 117, at 1884-85.

425. Muth v. Frank, 412 F.3d 808, 817 (7th Cir. 2005) (citing Mackey, 401 U.S. at 693 (Harlan, J., concurring in part and dissenting in part)); see also United States v. U.S. Coin \& Currency, 401 U.S. 715, 726-27 (1971) (Brennan, J., concurring) ("[A] decision holding certain conduct beyond the power of government to sanction or prohibit must be applied to prevent the continuing imposition of sanctions for conduct engaged in before the date of that decision."); Roosevelt, supra note 9, at 1122 ("If certain conduct is held constitutionally protected, the government loses the ability to punish it, and continued sanctions are imposed only in violation of the Constitution."); $c f$. Am. Steel Foundries v. Tri-City Central Trades Council, 257 U.S. 184, 201 (1921) ("[B] ecause relief by injunction operates in futuro, ... the right to it must be determined as of the time of the hearing").

426. Roosevelt, supra note 9, at 1122 n.237. Loving's holding-that states may not constitutionally criminalize miscegenation - is a classic example of a substantive rule.

We also note that relief for a habeas petitioner imprisoned in violation of a substantive rule of criminal law is likely a "constitutionally necessary remedy" under the analysis proposed by Professors Fallon and Meltzer. Fallon and Meltzer note that individual victims of past constitutional violations may not always obtain full relief. See Fallon \& Meltzer, supra note 26, at 1736. But relief from an ongoing constitutional violation — such as continuing imprisonment based on an unconstitutional conviction - is virtually always constitutionally required. See id. at $1808 \&$ n. 423 ("At one extreme [of the spectrum of new rules] lie rules and decisions that hold a defendant's conduct constitutionally immune from punishment. The protective purpose of such decisions, and of the underlying constitutional guarantees, clearly calls for retroactive application even of surprising holdings.").

427. INS v. St. Cyr, 533 U.S. 289, 301 (2001) (quoting Felker v. Turpin, 518 U.S. 651, 663-64 (1996)).

428. Id. at 301 n. 13. 
detention via the writ. ${ }^{429}$ In other words, the constitutional avoidance canon is particularly strong when the Suspension Clause is at issue because of the difficulty of reconstructing the original scope of habeas corpus and the attendant risk that a constitutional decision on the Suspension Clause would be in error.

Whether the scope of the writ in 1789 encompassed the situation under consideration - a petitioner wishing to obtain relief based on a substantive rule announced after his or her conviction - is perhaps debatable, but an affirmative answer is by no means implausible. As said, the rule requiring retroactive application of new substantive law can be traced directly to the original function of habeas corpus review of detention pursuant to judicial process: allowing a petitioner who was imprisoned by a court without jurisdiction of his or her case to obtain relief from confinement. Justice Harlan's analysis in Mackey- the foundation upon which modern retroactivity rests - makes this point pellucidly clear. ${ }^{430}$ If a court were to read section $2254(d)(1)$ to abrogate this venerable function of habeas review, it would have to face the difficult questions of what, precisely, the Suspension Clause protects and whether the retroactivity of substantive rules falls within that protection. Under St. Cyr, such questions should be avoided if at all possible. ${ }^{431}$

One final point is in order. Most, if not all, states currently allow a petitioner who seeks relief under a new substantive rule to file an application for postconviction relief on that basis in state court. ${ }^{432}$ Once the state habeas court rules on the merits of the claim, any subsequent federal review would be of that adjudication which applied the new rule ${ }^{43}$ — meaning the constitutional difficulty we have pointed out would often not arise. Nevertheless, this is not a sufficient answer to the problems discussed above, for a number of reasons.

First, there are strong arguments that the Suspension Clause imposes an affirmative obligation on the federal courts to make habeas relief available - that is, it does more than merely insuring that the writ may issue from some source. ${ }^{434}$

429. Id.

430. Mackey v. United States, 401 U.S. 667, 692-93 (1971) (Harlan, J., concurring in part and dissenting in part) (noting that habeas "has historically been available for attacking convictions" on the grounds that the conduct for which the defendant was convicted may not constitutionally be proscribed); see also FALLONET AL., supra note 9, at 1264. Granted, Congress did not allow federal courts to grant the writ of habeas corpus to prisoners confined under state (as opposed to federal) authority until 1867, see id. at 1157 (citing Act of February 5, 1867, 14 Stat. 385), which would tend to suggest that the writ did not extend to state prisoners at the Founding. But the Supreme Court has intimated that the historical scope of the writ may encompass state prisoners, and it certainly has not foreclosed that possibility. See Gerald L. Neuman, The Habeas Corpus Suspension Clause After Boumediene v. Bush, 110 ColuM. L. REV. 537, 562 (2010). For present purposes, it suffices to say that, as was the case in St. Cyr, the answer to the question is uncertain.

431. See generally St. Cyr, 533 U.S. at 289.

432. CJLF Whorton Brief, supra note 121, at *21-22 \& app.

433. See id.

434. See Neuman, supra note 430, at 557-58; cf. Boumediene v. Bush, 553 U.S. 733, 744 (2008) ("The Clause protects the rights of the detained by affirming the duty and authority of the 
If this is correct, then the availability of state collateral relief could not ameliorate any Suspension Clause problem; the Clause would still require the federal courts to have the power to issue the writ.

Second (a more general variation on the first point), courts should not adopt a construction of a federal statute that would otherwise raise serious constitutional problems on the basis that state law can step in to ameliorate the deficiency. State habeas law is not a constant. It could change at any time, and the constitutional interests at stake here are too important to leave to the caprice of state courts and legislatures.

Third, adopting a construction of the federal habeas statute reliant on the adequacy of state remedies would be akin to the rejected Kyl Amendment, which would have stripped the federal courts of jurisdiction to review state court determinations unless state court remedies were ineffective. And finally, there are still circumstances in which state courts cannot or will not give effect to retroactively applicable United States Supreme Court decisions. If a petitioner has raised a claim in state court once and then returns to state court for a second time following the operative United States Supreme Court decision, the state is still free to raise a successive litigation bar (and other procedural rules) and avoid reconsideration on state post-conviction review. In such a situation, the only court that could afford relief would be a federal habeas court, which would look through the state's asserted procedural default. ${ }^{435}$

In summary, given that $\S 2254(\mathrm{~d})(1)$ is subject to varying interpretations, application of the presumption against implied repeals of habeas jurisdiction and the constitutional doubt canon of statutory construction compels the conclusion that the statute should be construed to allow for the retroactive application of substantive rules. A contrary interpretation could allow a person convicted of an act that cannot constitutionally be prohibited, or subjected to a punishment that cannot constitutionally be imposed, to languish in prison without recourse. It is nearly unthinkable that Congress could have intended this result.

\section{CONCLUSION}

Some of the most difficult issues raised by the Supreme Court's retroactivity jurisprudence concern the meaning, scope, and theoretical foundation of the substantive-rule exception to the general principle of nonretroactivity of new

Judiciary to call the jailer to account.").

435. It is likewise no answer to the noted constitutional difficulties to hypothesize that the Supreme Court could use its authority to entertain original habeas petitions to afford relief to a petitioner wishing to rely on a new substantive rule. Cf. FALLON ET AL., supra note 9, at 297 (noting that the Court has, in the past, avoided questions about Congress's power to withdraw habeas jurisdiction from the federal courts "by holding that a statute withdrawing its certiorari jurisdiction in certain habeas corpus cases had not affected it authority to hear the case before it by entertaining a petition for an original writ of habeas corpus" (citing Felker v. Turpin, 518 U.S. 651 (1996); Ex parte McCardle, 74 U.S. (7 Wall.) 506 (1869))). Section 2254(d)(1), by its terms, is applicable to all federal habeas petitions, including those filed directly with the Supreme Court. 
rules on collateral review. This Article has aimed to illuminate those issues through examination of Miller v. Alabama and analysis of whether a habeas petitioner sentenced before that decision can rely on Miller under Teague and under $\S 2254(d)(1)$. The answer to both questions, we submit, is yes. Miller is at least partially retroactive under Teague because it includes an implicit substantive rule, and it is retroactive under $\S 2254(\mathrm{~d})(1)$ because that statute incorporates Teague's command that substantive rules apply retroactively on collateral review. These conclusions - which have been heavily informed by the historical and constitutional pedigree of the substantive-rule exception to nonretroactivity - are both legally sound and normatively attractive. Were the courts to conclude otherwise, the right to redress of an individual whose substantive due process rights have been violated would depend on the fortuity of the date that the decision recognizing those rights was handed down. Our constitutional system should not countenance such a result. 